\title{
Integrating policy, market, and technology for sustainability governance of agriculture- based biofuel and bioeconomic development in the US
}

\author{
Jianbang Gan ${ }^{1 *}$, Inge Stupak ${ }^{2}$ and C. T. Smith ${ }^{3}$
}

\begin{abstract}
The scaled-up production of biofuels and bioproducts in the US is likely to cause land use expansion and intensification domestically and internationally, possibly leading to undesirable environmental and socioeconomic consequences. Although these concerns have been widely recognized, sustainability governance systems are yet to be developed. Here, we review (1) the US bioenergy policies, (2) biofuel production and market trends, (3) major sustainability concerns, and (4) existing regulations and programs for sustainability governance, including potential interactions with markets and technology. US bioenergy policy dates back to the 1970s and has evolved over time with various tax incentives plus production mandates in recent key legislation. Commercial production of cellulosic biofuels is impeded largely by technology and cost barriers. Uncertainties exist in the estimates of environmental and socioeconomic impacts due to the lack of empirical data and knowledge of complex relationships among biofuel and bioeconomic development, natural ecosystems, and socioeconomic dimensions. There are various existing sustainability governance mechanisms on which a biofuel sustainability governance system can be built on. Considering all these, we propose an adaptive system that incorporates regulations, certification, social norms, market, and technology for sustainability monitoring and governance, and is able to contribute to addressing the overall environmental concerns associated with collective land use for food, fiber, and fuel production. Building on existing programs and mechanisms and with proper monitoring of biofuel and bioproduct development, such a governing system can be developed and implemented in response to sustainability concerns that may arise as biofuel and bioproduct production increases.
\end{abstract}

Keywords: Adaptive governance, Bioeconomy, Bioenergy, Complex interconnectivity, Land use, Uncertainty

\section{Background}

The United States (US) is one of the largest liquid biofuel producer and consumer countries in the world [1]. Liquid biofuels produced and consumed in the US so far are dominated by corn (grain)-based ethanol [2]. Thus, current sustainability issues associated with agriculturebased biofuels in the US stem primarily from the increased production and utilization of corn (grain) for biofuel production. Major sustainability (environmental, economic, and social) concerns related to corn ethanol

\footnotetext{
* Correspondence: j-gan@tamu.edu

${ }^{1}$ Department of Ecosystem Science and Management, Texas A\&M University, College Station, TX 77843, USA

Full list of author information is available at the end of the article
}

have centered on (a) expanded and more intensive use of land for corn production, which increases soil erosion and chemical (fertilizer, herbicide, and pesticide) use and leaching and impacts wildlife habitats, and (b) increased use of corn for ethanol production, which increases grain prices and likely causes indirect land use change (ILUC) and food security concern in less developed countries [3]. The existing sustainability governance for corn ethanol largely depends upon mandatory environmental regulations, voluntary conservation incentive programs, and best management practices.

Recently, the Energy Independence and Security Act (EISA) of 2007 has set an ambitious goal to increase biofuel shares in the US national energy profile by 
developing advanced and cellulosic biofuels [4]. According to the EISA, by the year 2022, the total biofuel output in the US will reach 136.3 billion liters (36 billion gallons) with 83.3 billion liters (22 billion gallons) of cellulosic and advanced biofuels. Achieving this production target for cellulosic biofuels demands a tremendous amount of biomass feedstock, including agriculturebased biomass such as crop residues, energy crops, and oilseeds, as well as biomass from forests and algae [5].

Increased production of agriculture-based biomass for biofuel production at this large scale could pose environmental, economic, and social sustainability concerns [6]. Addressing these concerns is challenging given the complex interactions and tradeoffs among production and markets for food, fuel, fiber, and ecosystem services such as water, biodiversity, and carbon. We explore some of these interactions and tradeoffs, to create a conceptual framework for developing a sustainability governance system for an agriculture-based biofuel and bioeconomic development in the US.

\section{Methods}

Our primary approach is first to examine and analyze if there is rationale for developing new specific sustainability governance system for an agriculture-based biofuel and bioeconomic development in the US. This will depend on the following:

1) The current and expected near-term production levels, if this is large enough to justify the effort needed to develop a specific new governance system at the moment. The analysis builds on a review of existing policies that support bioenergy deployment in the US, as well as review of the potentially available agricultural residues and land for energy crop production, and extent to which these resources are already used in biofuel production. It also explains the importance of R\&D investments.

2) The potential sustainability concerns associated with agriculture-based biofuel and bioeconomic development, and what is known about the extent to which they occur in different conditions. This analysis builds on a review of key sustainability concerns and impacts as described for the US in the existing literature.

Next, we examine the conditions for developing a new specific sustainability governance system for an agriculture-based biofuel and bioeconomic development in the US, including the following:

1) The extent to which the identified sustainability concerns and impacts are already addressed by existing sustainability governance. For this purpose, we review the existing relevant US regulations and state programs, private certification systems, and other voluntary non-state programs, including their scopes and the extent to which they are being applied.

2) The extent to which markets and technologies can influence aspects of sustainability governance. The analysis identifies interactions within and among the markets for fuels, food, and fiber, and discusses this in relation to financial instruments and other mechanisms for sustainability governance. It also reviews selected technologies that can potentially influence biomass and biofuel production and aid in monitoring and safeguarding sustainable biomass and biofuel production.

Finally, we suggest a conceptual framework with recommendations for developing a sustainability governance system for an agriculture-based biofuel and bioeconomic development in the US, based on the following:

1) A framework to understand what motivates behavioral changes, which is the ultimate aim of a governance system. The framework relies on a classification system for governance measures, as well as the concepts such as social norms and selfconsciousness.

2) Synthesis through logical reasoning based on the presented evidence and data, and the various analyses conducted to reveal relationships among relevant factors described above. Because of the interconnectivity among policy, market, and technology as well as their influences on the production and consumption of biomass, biofuels, and other bioproducts, we argue that they all should be considered and incorporated in the sustainability governance of biofuel and bioeconomic development along with other factors such as social norms and self-consciousness.

\section{US bioenergy policies and production US bioenergy policy}

US bioenergy policy dates back to the 1970s and has evolved over the past several decades (Table 1). Major policy goals have been (rural) economic development (income and jobs), national energy security (high oil prices and overreliance on imported oil), and greenhouse gas (GHG) emission mitigation. Key policy instruments have included production mandates (fuel blending requirements and production targets or quotas in the transportation sector), tax incentives or subsidies, biofuel import tariffs, and R\&D investments. The mandates and tax incentives/subsidies were designed to promote 
Table 1 Evolution of key federal legislation related to biofuel development in the US

\begin{tabular}{|c|c|c|c|c|}
\hline \multirow[t]{2}{*}{ Year } & \multirow[t]{2}{*}{ Act } & \multicolumn{2}{|c|}{$\begin{array}{l}\text { Major policy } \\
\text { instrument }\end{array}$} & \multirow[t]{2}{*}{ Key features in relation to bioenergy } \\
\hline & & $\begin{array}{l}\text { Tax } \\
\text { incentive } \\
\text { or subsidy }\end{array}$ & $\begin{array}{l}\text { Output } \\
\text { target/ } \\
\text { quota }\end{array}$ & \\
\hline 1970 & $\begin{array}{l}\text { Clean Air Act (CAA) of } 1970[7] \\
\text { with amendments of } 1990[8]\end{array}$ & & & $\begin{array}{l}\text { Authorized the development and implementation of regulations, } \\
\text { standards, and initiatives to limit air pollutants from both stationary and } \\
\text { mobile sources. }\end{array}$ \\
\hline 1978 & Energy Tax Act [9] & $x$ & & $\begin{array}{l}\text { Provided a tax exemption of US\$0.40 per gallon (US\$0.11/L) of ethanol (the } \\
\text { tax exemption is proportional for gasoline mixed with ethanol), in the } \\
\text { wake of the oil crisis. }\end{array}$ \\
\hline 1982 & $\begin{array}{l}\text { Surface Transportation Assistance } \\
\text { Act [10] }\end{array}$ & $x$ & & Increased the tax exemption to US\$0.50 per gallon (US\$0.13/L) of ethanol \\
\hline 1984 & $\begin{array}{l}\text { Tax Reform Act (amendment of } \\
\text { Deficit Reduction Act) [11] }\end{array}$ & $x$ & & $\begin{array}{l}\text { Further increased the tax exemption to US\$0.60 per gallon (US\$0.16/L) of } \\
\text { ethanol }\end{array}$ \\
\hline 1990 & $\begin{array}{l}\text { Omnibus Budget Reconciliation } \\
\text { Act [12] }\end{array}$ & $x$ & & $\begin{array}{l}\text { Extended the ethanol tax exemption through } 2000 \text { (but decreased it to } \\
\text { US\$0.54 per gallon }(\text { US } \$ 0.14 / L) \text { ). }\end{array}$ \\
\hline 1992 & $\begin{array}{l}\text { Energy Policy Act (EPAct) } \\
\text { of } 1992[13]\end{array}$ & $x$ & & $\begin{array}{l}\text { Encouraged the use of alternative fuels including biofuels to reduce } \\
\text { dependence on petroleum and improve air quality. }\end{array}$ \\
\hline 1998 & $\begin{array}{l}\text { Transportation Equity Act of the } \\
21 \text { st Century [14] }\end{array}$ & $x$ & & $\begin{array}{l}\text { Extended the ethanol tax exemption through } 2007 \text { (reduced to US\$0.51 } \\
\text { per gallon (US\$0.13/L) by 2005). }\end{array}$ \\
\hline 2004 & Job Creation Act [15] & $x$ & & $\begin{array}{l}\text { Extended the ethanol tax exemption to } 2010 \text { but changed it from an } \\
\text { excise tax exemption to a blender tax credit. The tax credit was later } \\
\text { decreased to US\$0.45 per gallon (US\$0.12/L). }\end{array}$ \\
\hline 2005 & $\begin{array}{l}\text { Energy Policy Act (EPAct) } \\
\text { of } 2005 \text { [16] }\end{array}$ & $x$ & $x$ & $\begin{array}{l}\text { Authorized the Renewable Fuel Standard (RFS) program to reduce } \\
\text { greenhouse gas emissions and expand the nation's renewable fuels sector } \\
\text { while reducing reliance on imported oil. Aimed at increasing renewable } \\
\text { fuel production from } 4 \text { billion gallons ( } 15.1 \text { billion liters) in } 2006 \text { to } 7.5 \\
\text { billion gallons ( } 28.4 \text { billion liters) by } 2012 \text {. Provided tax credits for } \\
\text { alternative fuel producers, infrastructure and motor vehicles. }\end{array}$ \\
\hline 2007 & $\begin{array}{l}\text { Energy Independence and } \\
\text { Security Act (EISA) [4] }\end{array}$ & $x$ & $x$ & $\begin{array}{l}\text { - Greatly expanded the biofuel blending mandates, requiring } \\
\text { transportation fuels sold in the US to contain a minimum of } 36 \text { billion } \\
\text { gallons ( } 136.3 \text { billion liters) of renewable fuels by } 2022 \text {. } \\
\text { - Covered four types of biofuels: renewable fuels (including corn-based } \\
\text { ethanol), advanced biofuels, biomass-based diesel, and cellulosic biofuels. } \\
\text { - Encouraged research and development of the next generation of biofuels, } \\
\text { such as cellulosic fuels. The cellulosic biofuels mandate was set at } 16.9 \text { billion } \\
\text { gallons ( } 64 \text { billion liters) by } 2022 \text {. } \\
\text { - Aimed to create a market for biofuels by requiring biofuel blenders to have } \\
\text { minimum volumes of biofuels in their annual transportation fuel sales under } \\
\text { the expanded RFS. } \\
\text { - Set certain minimum thresholds of lifecycle greenhouse-gas-emission performance } \\
\text { for each category of biofuel. }\end{array}$ \\
\hline 2008 & $\begin{array}{l}\text { Energy Improvement and } \\
\text { Extension Act [17] }\end{array}$ & $x$ & & $\begin{array}{l}\text { Extended biodiesel production and alternative fuel exercise tax credits through } \\
2009 \text { and alternative fuel infrastructure tax credit through } 2010 \text {. }\end{array}$ \\
\hline 2008 & $\begin{array}{l}\text { Farm Bill: Food, Conservation, and } \\
\text { Energy Act [18] }\end{array}$ & $x$ & & $\begin{array}{l}\text { Authorized the Biomass Crop Assistance Program (BCAP) to provide financial } \\
\text { assistance to individuals and companies for growing perennial crops and harvesting } \\
\text { and delivering cellulosic biomass feedstock for biofuel production. Set new cellulosic } \\
\text { biofuel producer credit at US\$1.10 per gallon (US\$0.29/L). }\end{array}$ \\
\hline 2010 & $\begin{array}{l}\text { Tax Relief, Unemployment } \\
\text { Insurance Reauthorization, and } \\
\text { Job Creation Act [19] }\end{array}$ & $x$ & & Extended and reinstated several alternative fuel tax credits through 2011. \\
\hline 2012 & American Taxpayer Relief Act [20] & $x$ & & Extended and reinstated several alternative fuel tax credits through 2013. \\
\hline 2014 & Tax Increase Prevention Act [21] & $x$ & & Retroactively reinstated several alternative fuel tax credits through 2014. \\
\hline 2014 & Farm Bill: Agricultural Act [22] & $x$ & & $\begin{array}{l}\text { Amended the BCAP to allow the enrollment of land under Conservation Reserve } \\
\text { Program or Agricultural Conservation Easement Program contracts. }\end{array}$ \\
\hline 2016 & $\begin{array}{l}\text { Consolidated Appropriations } \\
\text { Act [23] }\end{array}$ & $x$ & & $\begin{array}{l}\text { Retroactively reinstated and extended several alternative fuel tax credits } \\
\text { through } 2016 .\end{array}$ \\
\hline
\end{tabular}


domestic biofuel production and consumption while the import tariffs were intended to protect the developing domestic biofuel industry from damaging competition from foreign producers [24]. The R\&D investments aimed to develop and commercialize cutting-edge technologies to reduce biofuel production costs and thus to foster biofuel market proliferation.

Prior to 2005, polices relied on providing tax breaks or other incentives including financial and technical assistance to biomass and bioenergy producers and fuel blenders to promote biofuel production. These earlier policies were relatively narrowly focused in terms of policy objectives and instruments used. Rural economic development and job creation as well as energy security were the primary policy drivers. As such, tax incentives and subsidies were the main policy instruments. On the other hand, later policies, especially the Energy Policy Act of 2005 [16] and the EISA of 2007 [4], have directly set mandated biofuel production quotas, although tax incentives and subsidies are still part of the overall policy instruments, to achieve multiple objectives like energy security, GHG emissions, job creation, and economic development. Based on the statutory targets with adjustments, the US Environmental Protection Agency (EPA) develops Annual Renewable Fuel Standards (RFS) (or Annual Volume Standards) for various categories of biofuels as required by the Clean Air Act $[7,8]$ in the context of air quality.

One recent incentive program is the Biomass Crop Assistance Program, authorized by the Food, Conservation, and Energy Act of 2008 (i.e., the 2008 Farm Bill) [18], which provides financial assistance to agricultural and forest land owners and operators for producing and delivering biomass feedstock for conversion to bioenergy. Furthermore, the Office of Energy Efficiency and Renewable Energy (EERE, US Department of Energy) supports $R \& D$ investments, which are essential to solving the technology bottleneck of second-generation biofuels. Recent $R \& D$ investments have targeted key technologies pertinent to biomass production and logistics, biomass- to-biofuel conversion, and integrated biorefineries and distribution infrastructure as well as crosscutting issues for technology adoption and sustainability [25].

Prior to 2007, policies were focused on corn-based ethanol (i.e., first-generation biofuel). As the concern about the impact of using corn for fuel production on world food prices and supply loomed, recent policies, especially the EISA of 2007, stressed the development of biofuels derived from non-food-based feedstocks, e.g., cellulosic and advanced biofuels or second-generation biofuels [4]. This switch in feedstock sources from grainto non-grain-based biomass is expected to lessen the impact on food markets and land and reduce GHG emissions [4]; however, large-scale or intensive production of non-grain-based biomass produced from land can still exert tremendous pressure on land use, potentially leading to unsustainable development [6].

In summary, high oil prices, energy security concerns, and rural income and economic development were primary drivers for the early bioenergy policies and regulations in the US. Environmental drivers especially GHG emission reductions have become important only in recent bioenergy policies and regulations. Although tax incentives and subsidies have been common instruments used in most US bioenergy policies, quotas (biofuel production/output targets) have been a focus of recent policies. R\&D investments have become increasingly important to overcome technological and economic barriers to market penetration of second-generation biofuels, while also considering sustainability issues. The evolution of drivers, objectives, and instruments of US bioenergy policy and regulations is expected to continue as economic, social, environmental, and political conditions change, as history has indicated.

\section{Land use and agricultural crop production in the US}

There are approximately 145.7 million hectares (360 million acres) of cropland in the US, occupying about $17 \%$ of total land area (Fig. 1). The land used for crop production has been relatively stable in the past three
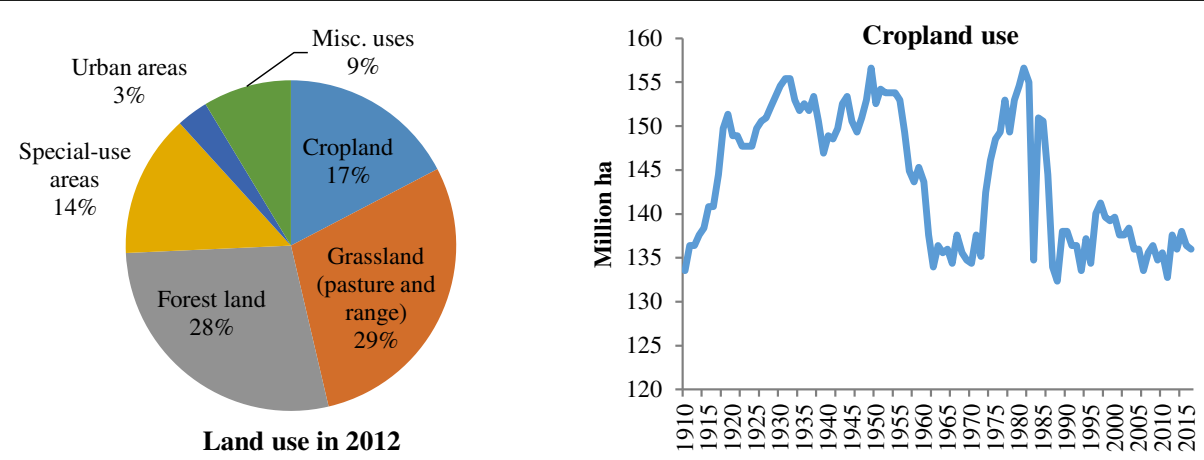

Fig. 1 Land use in 2012 and cropland use in 1910-2016 in the US [26] 
decades at a range of 133.5-141.6 million hectares (330350 million acres) (Fig. 1). Corn production, a major feedstock for corn ethanol, has been concentrated in the Corn Belt across the Midwest region.

Corn, soybean, and wheat production occupied almost the same acreage of cropland in 1997. Over the past 20 years, however, corn and soybean production in terms of both total output and areas planted or harvested has been on a rising trend, whereas wheat production has declined considerably (Fig. 2). The common rising trend of both corn and soybean production suggests that biofuel (corn ethanol) production is not the only driving force of cropland use because a much smaller portion of soybean output has been used for biofuel production compared to corn due to direct consumption by humans and utilization as animal feed [2]. Hence, sustainability issues associated with land use change possibly induced by bioenergy feedstock production should be and can only be effectively addressed in a broader context of the overall drivers of land use and cover change.

\section{Biofuel production in the US}

The use of corn for ethanol production has grown exponentially over the past three decades (Fig. 3). Although the EISA of 2007 has set an ambitious target for cellulosic biofuels, corn (grain) ethanol has continued to dominate the US biofuel production, and cellulosic biofuels are still in the development or demonstration stage (Fig. 3).

Major potential agriculture-based bioenergy feedstock sources for cellulosic biofuels in the US are crop residues and energy crops. Available crop residues include corn stover and wheat, barley, oat, and sorghum straw. Relevant non-food energy crops include switchgrass (Panicum virgatum), energy cane (Sacharum spontaneum), miscanthus (Miscanthus floridulus), and biomass sorghum (Sorghum bicolor L. Moench). The potential availability of these feedstock sources has been examined and appears significant in quantity [5]. Yet, their supply for biofuel production depends upon many factors including demands for grains and ecosystem services; competing uses among croplands, pasturelands, and marginal agricultural lands; prices of biomass; and uncertainties of biomass availability; among other ecological, environmental, economic, and social considerations. Among the potential crop residues identified, corn stover seems to be a dominant biomass source. There is no clearly dominant energy crop identified, and their potential will depend upon their yields, production cost, land availability, and other inputs required for their production $[28,29]$.

Although several cellulosic biofuel production plants have been in operation, their capacity is still low (Table 2) [2]. This happens even though supportive policies are in place, residue feedstocks are available, and considerable amounts of additional feedstocks can be potentially be produced from energy crops. In fact, the expansion of cellulosic biofuel production capacity in the US is constrained by several factors, mainly competition with petroleum fuels, high production costs, and policy uncertainty [30]. High production costs (both feedstock and feedstock-to-biofuel conversion costs) remain a major barrier to the expansion of commercial production of cellulosic biofuels. Low fossil fuel prices and the lack of incentives or mandates for GHG offsets as well as the uncertainty about the role of biofuels in GHG offsetting add additional challenges to cellulosic biofuel development. All these, however, can change, which will make cellulosic biofuels more competitive and beneficial and facilitate their market expansion.

\section{Market and technology development and sustainability governance}

The low production level and capacity of cellulosic biofuels at present and in the foreseeable future in the US means that sustainability issues associated with cellulosic biofuels do not yet exist, even if they may emerge in case
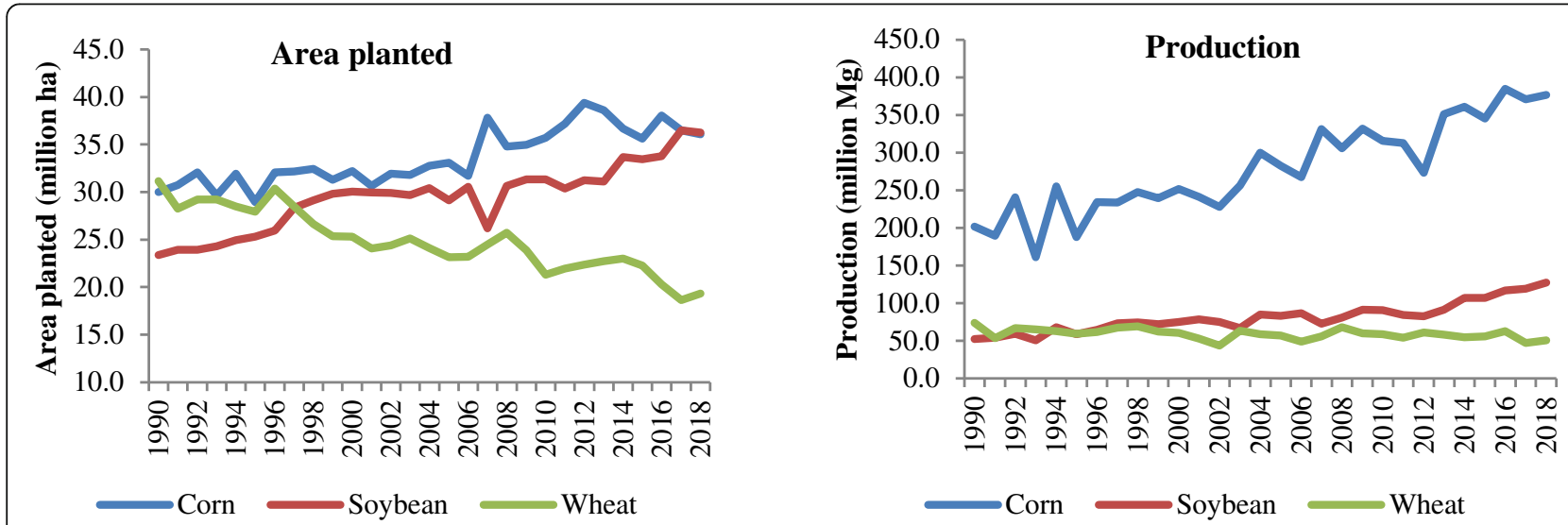

Fig. 2 Grain crop area and production in the US [27] 

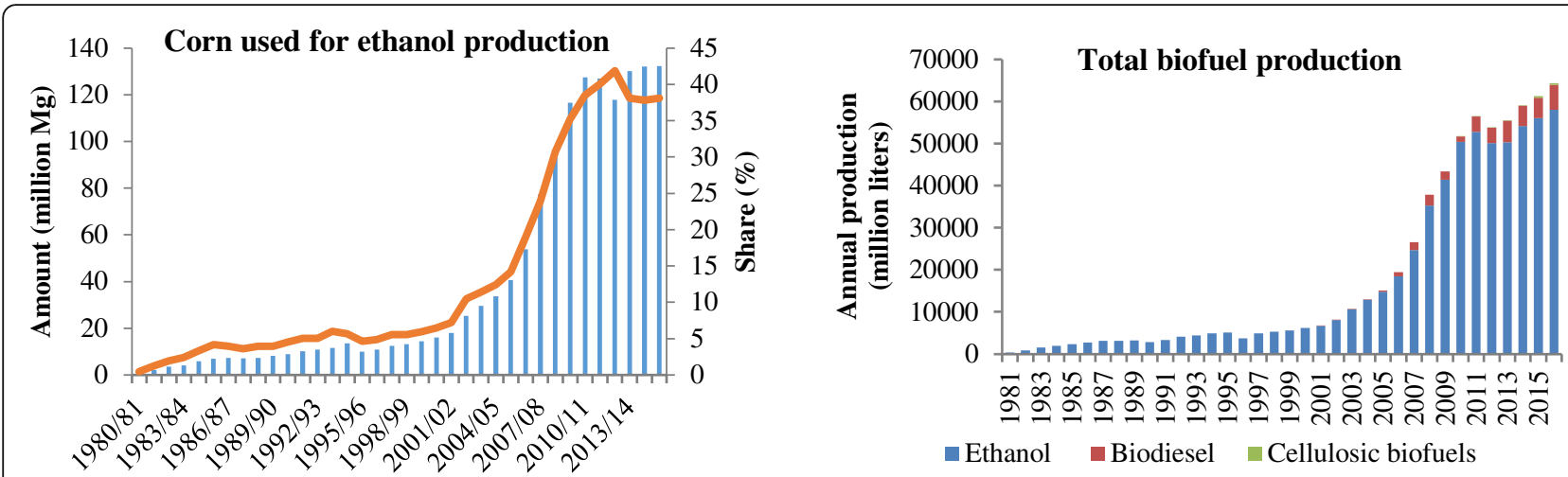

Fig. 3 Corn used for ethanol production and total biofuel production in the US [2]

the large-scale expansion of commercial cellulosic biofuel production becomes a reality. Altogether, this indicates that in spite of supportive policies, market and technology development may, to a larger extent, influence which type and amounts of biofuels are being produced. The fact that market (costs) and technology are currently barriers to biofuel development, however, implies that biofuel sustainability governance should monitor market and technology development and, whenever possible, guide market and technology development towards generating more sustainable outcomes.

Although large-scale production of cellulosic biofuels has not happened, research on sustainability governance seems necessary to prevent anticipated unsustainable environmental and socioeconomic impacts associated with the scaled-up production. Moreover, sustainability concerns associated with grain-based biofuels have mainly been inadequate GHG savings and adverse impacts on grain prices and food security $[3,6]$. The introduction of minimum requirements for GHG emission reductions and a production shift towards cellulosic and advanced biofuels were intended to address these issues [4]. Because the output targets of cellulosic and advanced biofuels have not been realized, these issues have not been resolved, calling for sustainability governance as the market develops.

\section{Sustainability concerns of agriculture-based biofuel production in the US}

Fulfilling the biofuel production targets established by the EISA of 2007 is generally expected to have positive environmental impacts for climate through reduction of GHG emissions, while other potential consequences have also been widely debated. Major concerns include those arising from direct and indirect land use changes (ILUC) and overharvesting of residues, as well as air quality, soil erosion and nutrient loss, water use and quality, and biodiversity [6]. Because these concerns are well known, here, we provide only a brief summary (Table 3) with some explanations on those specifically related to the US.

Table 2 Projected capacity of second-generation biofuel plants in the US, 2016-2017 [2]

\begin{tabular}{|c|c|c|c|}
\hline Company & Location & Fuel type & Annual volume (million liters) \\
\hline \multicolumn{4}{|l|}{$2017 / 2018$} \\
\hline DuPont & Nevada, IA & Ethanol & 114 \\
\hline Poet & Emmetsburg, IA & Ethanol & 91 \\
\hline OCCP & Galva, IA & Ethanol & 15 \\
\hline Total & & & 220 \\
\hline \multicolumn{4}{|l|}{2016} \\
\hline Abengoa & Hugoton, KS & Ethanol & 95 \\
\hline Cool Planet & Alexandria, LA & Gasoline & 4 \\
\hline DuPont & Nevada, IA & Ethanol & 114 \\
\hline INEOS Bio & Vero Beach, FL & Ethanol & 30 \\
\hline Poet & Emmetsburg, IA & Ethanol & 91 \\
\hline OCCP & Galva, IA & Ethanol & 8 \\
\hline Total & & & 341 \\
\hline
\end{tabular}


Table 3 Major environmental concerns associated with large-scale biomass and biofuel production

\begin{tabular}{|c|c|}
\hline Issue & Unfavorable consequences \\
\hline $\begin{array}{l}\text { Land use change (direct and } \\
\text { indirect) }\end{array}$ & $\begin{array}{l}\text { Entailing economic incentives and a large amount of land to grow perennial biomass to meet the Renewable Fuel } \\
\text { Standards [31] } \\
\text { Transnational indirect land use (ILUC) including deforestation elsewhere [32, 33] } \\
\text { Estimation difficulty [34] }\end{array}$ \\
\hline Overharvesting of crop residues & $\begin{array}{l}\text { Overharvesting due to cost savings [35] } \\
\text { Overharvesting due to temporal and spatial yield variations }[29,36,37]\end{array}$ \\
\hline Greenhouse gas (GHG) emissions & $\begin{array}{l}\text { Varying from case to case [38] } \\
\text { Emissions associated with ILUC [32, 33] } \\
\text { Measurement difficulty }[39,40]\end{array}$ \\
\hline Soil erosion and nutrient loss & $\begin{array}{l}\text { Varying from case to case }[41,42] \\
\text { A potential limiting factor for residue removals in some locations [37] }\end{array}$ \\
\hline Air quality & $\begin{array}{l}\text { Increased emissions of } \mathrm{PM}_{1} \mathrm{O}_{3} \text {, and } \mathrm{SO}_{x}[6] \text { and } \mathrm{NO}_{x}[43] \\
\text { Varying from case to case [44] }\end{array}$ \\
\hline Water use & Increased water use for feedstock production $[44,45]$, especially in areas already facing water shortage $[41,46]$ \\
\hline Water quality & $\begin{array}{l}\text { Increased chemical use for biomass production }[38,45] \text { or supplementing soil nutrient loss from } \\
\text { residue removals }[47-49]\end{array}$ \\
\hline Biodiversity & $\begin{array}{l}\text { Varying from case to case and unknown impacts [38, 50, 51] } \\
\text { Impacting locally important wildlife species [52] } \\
\text { Habitat alterations by feedstock production [53], especially monoculture plantations [54-56] } \\
\text { Risk associated with introduction of genetically modified or non-native plant species [54, 56-59] }\end{array}$ \\
\hline
\end{tabular}

\section{Direct and indirect land use change}

To meet the biofuel production targets established by the EISA, it is likely to directly and indirectly induce the expansion of land used for growing grain crops and energy/biomass crops and the intensification of current cropland management. Domestically, an area of non-cropland (e.g., marginal lands) equivalent to over 10\% (16-20 million hectares) of current total cropland area is needed to grow perennial biomass crops in order to meet the EISA's cellulosic biofuel target although actual production of biomass from marginal lands will be constrained by not only the physical availability of these lands but also farmers' willingness to use marginal lands for biomass production [31]. Internationally, the expansion of biofuel production in the US could lead to ILUC, especially conversions of forestlands and other environmentally important or sensitive lands for agricultural production in other parts of the world [32, 33]. Yet, quantifying the ILUC induced by biofuel production is challenging given the complexity of land use drivers and their interconnectivity and is estimated primarily via modeling, yielding a wide range of results [34]. Without accurate estimates of ILUC consequences, governance for mitigating the ILUC impacts remains challenging and mechanisms for monitoring and preventing the ILUC seem necessary.

\section{Intentional and unintentional overharvesting of crop residues}

Motivated by economies of scale, biomass producers have a tendency to collect more biomass at a location to reduce its collection and transport costs, thus lowering overall biofuel or bioproduct costs. Moreover, if greater amounts of biomass are harvested from a more limited geographic area, it will result in a shorter biomass supply radius to meet a specific capacity of a conversion plant, exponentially reducing the unit cost of biomass transport and ultimately biofuel production (Fig. 4) [35]. Thus, biomass harvesters (biomass suppliers or contractors not farmers) and biofuel conversion plant operators have incentives to intensify collection of biomass at a specific location. This could lead to intentional overharvesting of biomass in a concentrated area, causing longterm soil productivity and carbon loss, excessive soil and water erosion, and biodiversity degradation.

Additionally, biomass yield can change considerably from year to year at a given location, and soil type and conditions as well as other environmental constraints may even vary across a farm field. These variations increase the complexity required to precisely determine and harvest different amounts of biomass (e.g., crop residues) in different years and locations to avoid severe soil erosion and nutrient loss and other negative environmental impacts [29, 36, 37]. This is a difficult task for farm operators and may unintentionally result in overharvesting of biomass in some years or locations. Therefore, mechanisms and tools for preventing both intentional and unintentional biomass overharvesting need to be addressed and developed.

\section{Greenhouse gas emission savings}

Biofuels are expected to offset GHG emissions from the production and consumption of fossil fuels. Yet, GHG consequences of biofuels vary with biofuel type, feedstock 


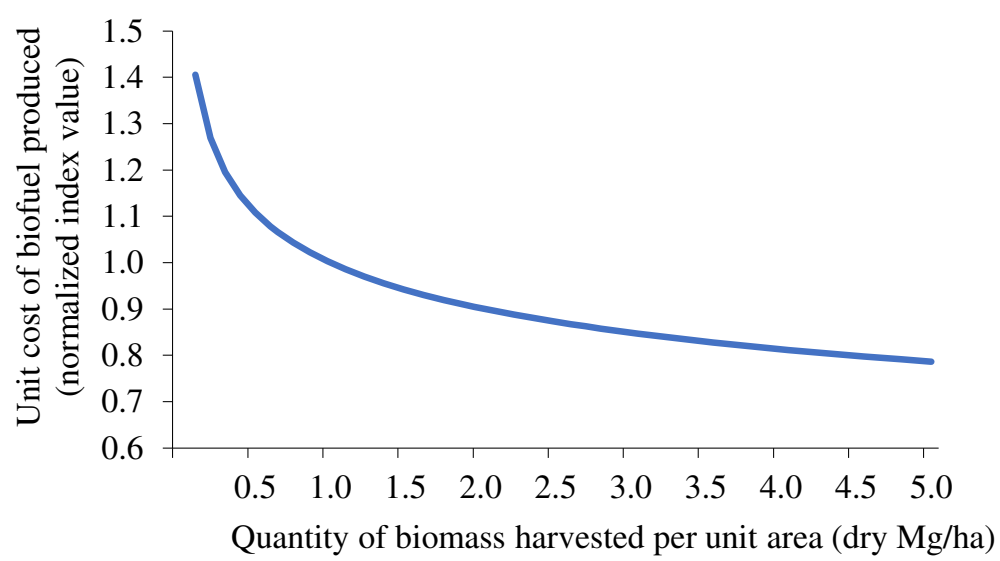

Fig. 4 The relationship between the unit cost of biofuel production and the quantity of biomass harvested per unit area (adopted from [35])

used, production processes, and GHG accounting methods, among other things [38]. Concerns about no GHG advantage of some biofuels (e.g., corn-based ethanol) relative to fossil fuels, if indirect land use change is accounted for, have been raised recently $[32,33]$. Some researchers, however, argue that biofuel-induced ILUC and associated GHG emissions may be overstated [39], calling for improved modeling and estimation methods [40]. Such uncertainties are major barriers for policy makers to create stronger policy incentives for biofuel deployment as well as developing and implementing other sustainability governance.

\section{Air quality}

While emissions of greenhouse gasses are generally expected to decrease, the emissions of particulate matter, ozone, and sulfur oxide may increase during combustion of biomass-based ethanol due to its higher content of these pollutants compared to petroleum-based fuels [6]. Corn stover-based ethanol could generate much higher nitrogen oxide emissions than gasoline [43]. On the other hand, biomass feedstock (corn stover and herbaceous energy crops) production, in general, would generate less direct air pollution than conventional corn and soybean production primarily because of lower chemical inputs [41]. Overall, the impacts of agriculture-based biofuel production and consumption on air quality vary from case to case [44].

\section{Soil erosion and nutrient loss}

Excessive residue removals and expanded and more intensive land use could cause more soil erosion and nutrient loss, affecting long-term soil health and productivity. Yet, estimating sustainable crop residue removal rates is difficult, entailing consideration of many factors including farming practices, climate, and soil type [44] as well as the objectives for maintaining soil organic matter and carbon
[42]. As a result, there is a wide range of variations in recent estimates of the sustainable corn stover removal rate $(0-75 \%)$. A case study in Iowa indicates that soil erosion and nutrient loss may become an issue only for certain soil type and terrain conditions [37].

The impact of herbaceous energy crop production on soil would largely depend upon the previous land use. On cultivated land, perennial energy crops tend to have moderately positive impacts on soil quality because of less intensive tillage and reduced chemical use. Additionally, the deeper root system and year-round land cover of perennial crops help reduce soil erosion and increase soil organic matter and carbon in the long term [44]. Planting herbaceous crops as stream buffer strips can also reduce soil erosion and chemical runoff from adjacent cropland [60].

\section{Water use and quality}

The water use concern associated with biofuel development would be more locally rather than nationally significant [41]. About $42 \%$ of total freshwater withdrawals in the US were for crop irrigation in 2015 [46]. Feedstock and biofuel production will increase water use for irrigation and biofuel milling [44, 45], creating additional pressure for some areas (especially western parts of the country) where water is already a big constraint to agricultural production [46]. Additionally, increased use of agricultural chemicals for feedstock production, and expanded and more intensive land use can affect water quality $[38,45]$.

Collecting crop residues is unlikely to significantly increase water use. However, additional fertilizer use to replenish the soil nutrition loss and increased soil erosion resulting from residue removals may adversely affect water quality [47-49].

\section{Biodiversity}

The impacts of biomass production on biodiversity vary with feedstock type, production method, scale, location, 
associated land use change, and other factors [38, 50, 51]. Removals of crop residues would not dramatically change the spatial patterns of habitats, but there could be negative effects on some wildlife species such as pheasants if an excessive amount of corn stover is harvested [52]. Herbaceous energy crop plantations can have positive or negative impacts on biodiversity. Growing herbaceous energy crops on marginal land can help improve landscape restoration, biodiversity, and natural habitats $[50,53,61]$. However, negative effects on wildlife habitats and biodiversity can result from monoculture plantations [54-56], alterations of spatial land use patterns [53], and introduction of genetically modified or non-native plant species [54, 56-59].

\section{Interlinkages and uncertainties}

These consequences of cellulosic biofuel feedstock production are essentially site specific and will depend upon what, where, how much, and how biomass and biofuels will be produced $[38,44,52]$. Even when all these factors are known, there are enormous uncertainties associated with the environmental consequences of biofuel development, as the socioeconomic and biophysical interrelationships pertinent to biofuel production and consumption are very complex and there is lack of data to quantify these relationships. This complicates creation of simpler and more effective regulations with minimum administrative burdens and costs.

\section{Existing sustainability governance mechanisms}

A governance system typically consists of mandatory and voluntary components. These two components interact (ideally complement) each other to achieve desirable objectives or outcomes. This section provides a brief review of existing mandatory and voluntary mechanisms or programs that govern sustainability of agriculture-based biofuel and bioeconomic development as well as other forces and factors that can potentially interplay with these existing mechanisms or programs in the US biofuel and bioeconomic sectors.

Currently, mandatory programs are essentially regulations, and voluntary programs mainly include conservation incentive or assistance programs and best management practices (BMPs). Existing relevant regulations primarily include those protecting air, water, soil, and endangered species (Table 4). These regulations, incentive programs, and BMPs were established prior to recent bioenergy initiatives. Thus, they were not intended to mitigate the specific environmental impacts of biofuel development. To complement these regulations and voluntary programs, bioenergy certification has been discussed and proposed, but it has not been implemented in the US partially because the production of second-generation biofuels has not commercially scaled up.

There are many other forces or factors that could interact with the existing mandatory regulations and voluntary programs. Among them are markets and technologies, including the markets of other energy sources and technologies that can help monitor and reduce the negative impacts of biomass and bioenergy production and consumption on GHG emissions, air, water, soil, and wildlife habitats.

\section{Policy and government programs}

Government regulations and programs include mandatory requirements or compliances (sticks) and voluntary incentives (carrots). While regulations impose mandatory requirements for protecting the environment and conserving natural resources with penalties for noncompliances, incentive programs offer financial and technical assistance to stakeholders to induce and help them to meet the regulatory requirements and/or implement additional conservation efforts beyond the requirements.

\section{Mandatory programs (regulations)}

Recent energy or bioenergy regulations like the EISA of 2007 do not cover a wide range of specific requirements for environmental protection. A major mandatory environmental requirement specified in the EISA is the GHG emission reductions for advanced and cellulosic biofuels relative to a fossil fuel reference. However, biofuel development must also be in compliance with existing laws and regulations. Some major existing environmental regulations in the US, which are applicable to the

Table 4 Existing regulations and programs applicable to governing sustainability of biofuel and bioeconomic development in the US

\begin{tabular}{llll}
\hline Major concern addressed & Regulation & Conservation incentive program & Other voluntary program \\
\hline Soil erosion & SWRCA & CSP & BMP \\
Water quality & CWA, SWRCA & EQIP & \\
Air quality/GHG emissions & CAA, EISA & LCI & \\
Biodiversity & ESA & AMAP & \\
\hline
\end{tabular}

AMAP Agricultural Management Assistance Program [62], BMP best management practices [63], CAA The Clean Air Acts (1963 and 1970 , amended in 1977 and 1990) [8], CSBP Council on Sustainable Biomass Production (not implemented) [64], CSP Conservation Stewardship Program [62], CWA The Clean Water Act (1972, amended in 1977 and 1987) [65], EISA The Energy Independence and Security Act [4], EQIP Environmental Quality Incentives Program [62], ESA The Endangered Species Act (1973) [66], LCI Landscape Conservation Incentives [62], SWRCA The Soil and Water Resources Conservation Act (1977) [67] 
production, trade, and consumption of agriculture-based biofuels and bioproducts, include the following:

- The Clean Air Act

- The Clean Water Act

- The Soil and Water Resources Conservation Act

- The Endangered Species Act

The Clean Air Act (CAA) regulates air emissions from stationary and mobile sources. The Act was originally established in 1963 and amended several times with its latest amendments of 1990. It authorizes the US EPA to establish the National Ambient Air Quality Standards (NAAQS) to protect public health and welfare from risks associated with the emissions of hazardous air pollutants. The initial Act required all states in the US to meet the NAAQS by 1975 . The subsequent amendments set new dates for achieving the NAAQS largely because many parts of the country could not meet the initial target date. The 1990 amendments revised Section 112 to first require the issuance of technology-based standards for a stationary or group of stationary sources including major and non-major (certain area) sources [8].

The Federal Water Pollution Control Act Amendments of 1972 [65], commonly referred to as the Clean Water Act, was built on the Federal Water Pollution Control Act enacted in 1948. It regulates discharges of pollutants into waters and quality standards for surface waters in the US. Authorized by this Act, US EPA has established and implemented pollution control programs including wastewater standards for industry and water quality standards for all contaminants in surface waters. Also, under this law, it is unlawful to discharge any pollutant from a point source into navigable waters without a permit.

The Soil and Water Resources Conservation Act of 1977 [67] authorized the US Department of Agriculture (USDA) to develop and implement natural resource conservation programs to meet the nation's long-term needs. Under this law, USDA is directed to conduct periodic assessments of the soil, water, and related resources in the US (including the status, conditions, and trends of these resources); analyze land and water resource problems; and identify alternative solutions to such problems. Over the years, USDA has collected a tremendous amount of data on natural resource inventory and completed many assessment reports, which provide an overview of land use, natural resources, and the agriculture and forestry sectors in the US while monitoring and assessing the status, conditions, and trends of soil, water, and related natural resources in the country [68].

The Endangered Species Act of 1973 [66] authorized the US Fish and Wildlife Service (FWS), National
Oceanic and Atmospheric Administration (NOAA) Fisheries Service, and other federal agencies to develop and implement programs to conserve and protect threatened and endangered plants and animals and their habitats. The FWS establishes and updates the list of threatened and endangered species, including birds, insects, fish, reptiles, mammals, crustaceans, flowers, grasses, and trees. The law protects from jeopardizing the continued existence of listed species or destructing or adversely modifying their designated critical habitats, and prohibits the "taking" and trade of these species.

These environmental regulations were established long before the biofuel mandates (e.g., EISA). Compliance with these environmental regulations can address many environmental concerns associated with biofuel and bioeconomic development, such as air quality, soil and water conservation, natural resource monitoring, and endangered species protection. Although GHG emissions are not directly specified in these previous regulations, compliance with the Clean Air Act can be linked, to some extent, to controlling GHG emissions, as the EPA has done. Moreover, the EISA has established specific lifecycle GHG emission requirements for biofuels. The required emission reduction from the 2005 petroleum baseline is $20 \%, 50 \%$, and $60 \%$ for conventional ethanol, advanced biofuels, and cellulosic ethanol, respectively [4].

\section{Voluntary incentive programs}

There are several current voluntary incentive programs applicable to agriculture-based biomass and bioproduct production. Most of these programs were not originally designed for biofuel programs and have been implemented for a while, but they are still relevant for the production of agriculture-based biomass and products. These programs can change over time. The following are a few of most widely known voluntary programs that are currently managed by the USDA Natural Resources Conservation Service (NRCS) [62].

\section{Conservation incentive or assistant programs}

There are many conservation incentive or assistance programs that have been established and implemented in the US. These programs provide financial and/or technical assistance to encourage stakeholders (landowners, agricultural and forestry producers, and conservation practitioners) to protect and conserve natural resources and the environment that are also important to sustaining their agricultural and forestry production in particular and the quality of life in general. Some programs have expired, and yet new programs have emerged. Some programs have also evolved over time. Currently, several of these programs are relevant to agriculture-based biomass and biofuel production. 
Landscape Conservation Initiatives This program, established under the 2008 Farm Bill, aims to promote locally-driven conservation processes to address the conservation issues that are of regional and national importance. This program focuses on landscape-level efforts initiated at the local level but with impacts that transcend local boundaries. Effective partnerships are further emphasized for this program under the 2014 Farm Bill. Existing efforts supported by this program include water-, wildlife-, and ecosystem-based initiatives, and other landscape-level efforts, leading to cleaner water and air, healthier soil, and enhanced wildlife habitat.

Agricultural Management Assistance Program This program provides financial and technical assistance to farmers in 16 states to encourage them to incorporate conservation into their production processes to address water management, water quality, and erosion control issues. This program offers cost sharing for installing conservation practices, risk mitigation through production diversification and conservation practices, tree planting for windbreaks or water quality improvement, and other agricultural and forestry practices. The 16 eligible states include Connecticut, Delaware, Hawaii, Maine, Maryland, Massachusetts, Nevada, New Hampshire, New Jersey, New York, Pennsylvania, Rhode Island, Utah, Vermont, West Virginia, and Wyoming, where participation in the Federal Crop Insurance Program is historically low.

Conservation Stewardship Program This is the largest conservation program in the US with 312 million hectares (770 million acres) of agricultural and forest lands enrolled. This program focuses on promoting conservation enhancements to agricultural and forestry producers who have already implemented some conservation practices. There is a broad scope of conservation efforts eligible for this program, ranging from planting cover crops to implementing conservation tillage practices and to managing forests to improve wildlife habitats. NRCS personnel provide a oneon-one consultation to an interested producer to develop a tailored conservation plan. The program provides payments and technical assistance for both maintaining existing conservation activities and implementing additional or new conservation efforts.

Environmental Quality Incentives Program This program focuses on the conservation practices that enhance soil, water, air, plants, animals, and other natural resources on agricultural land and non-industrial private forestland. It provides both financial and technical assistance to producers to implement voluntary conservation practices and/or to comply with federal, state, and local regulations. It aims to address priority natural resource concerns on the most vulnerable land and in high priority watersheds. The program offers a variety of conservation practices tailored to meet specific conservation needs and goals of a producer, including residue and tillage management, forage and biomass planting, forage harvest management, forest stand improvement, and many other practices.

\section{Best management practices}

Agricultural best management practices (BMPs) also help achieve natural resource conservation and environmental protection such as reducing soil erosion and improving water quality through adopting and adjusting agricultural and forest land management practices. BMP guidelines can be developed by government agencies or industry groups. Unlike conservation incentive programs, producers/farmers do not receive payments or cost sharing by adopting BMPs. Adopting BMPs is usually voluntary.

There are a wide range of agricultural BMPs, including cover crops, contour farming, conservation tillage, terraces, strip cropping, streamside vegetative buffers, irrigation efficiency, and agroforestry, among others. Water protection (quality and quantity) has been a major emphasis of BMPs. In this aspect, agricultural BMPs primarily focus on modifying cropland management practices to reduce soil erosion and nutrient runoff to protect water resources for the purposes of drinking, recreation, animal habitat, fisheries, livestock, irrigation, and other uses.

\section{Certification}

Sustainability certification programs are also voluntary, though different from government incentive programs. Certification is a non-governmental, market-based approach to sustainability governance, designed to demonstrate compliance with legislation or a certain standard that complements regulatory requirements (Mansoor $\mathrm{M}$, Stupak I, Smith CT et al.: Trust and Legitimacy in Sustainability Governance of Bioenergy Supply Chains, in preparation). Compared to legislative actions or the public policy making process, in certification programs, non-state actors such as non-governmental organizations (NGOs), industries, and consumers play a vital role in rule-making [69]. However, current certification schemes in general are, to varying extents, criticized for lack of credibility, consistency, and transparency [70]. Additionally, certification incurs costs including a fee to the certification scheme, putting in place required management systems, and collecting documentation to demonstrate that the certification standards are being met. The key benefits for producers to enroll in a certification program may, for example, be to meet legislative requirements, gain market access to certified markets, and/or obtain a price premium [71]. For a producer to participate in a certification scheme, these benefits should outweigh the costs. 
There are several bioenergy certification schemes that have been developed and/or implemented around the world [70]. Some of them focus on domestic and regional markets or a specific bioenergy product; others cover global markets or multiple bioenergy products (Table 5).

To our knowledge, there is no biofuel certification scheme currently operating in the US, although a considerable amount of work has been done on developing principles, criteria, and indicators for safeguarding biofuel sustainability $[64,79]$. The current nonexistence of bioenergy certification schemes in the US may be partly due to the lack of government legislation to meet higher standards for bioenergy and markets for certified bioenergy products, the two major drivers/incentives for bioenergy certification. These could change if bioenergy production scales up to the targets established by the EISA of 2007. If US markets will at some point require that sustainability standards be met, future bioenergy certification schemes could build on the work by the Council on Sustainable Biomass Production (CSBP) [64] and experiences from other certification schemes implemented in other parts of the world, such as those (Table 5) to meet the sustainability requirements of the European Union Renewable Energy Directive (2009) [78].

In lieu of literature reviews and synthesis, we offer a few suggestions for a possible future biofuel and bioproduct certification schemes in the US. First, a biofuel and bioproduct certification scheme should address the concerns that have not been addressed by existing legislation such as ILUC, food-fuel-feed conflict, long-term soil productivity, wildlife, and biodiversity, thereby maximizing its complementarity to government policy and enhancing the benefits of the certification scheme.
Second, a biofuel and bioproduct certification scheme should be as simple as possible in terms of principles, criteria, and indicators by focusing on key concerns and issues from a systems perspective. Taking a systems perspective here means considering direct and indirect impacts (environmental, economic, and social) and economic sectors closely related to the biofuel and bioproduct sectors simultaneously and across spatial and temporal scales. Only in this way can the certification scheme add value, be more widely adopted, and better complement existing regulations. The interlinkages among the different components of a mixed natural and human system associated with biofuel and bioproduct production and consumption make this approach possible. In other words, when things are interconnected, there is no need to control everything to achieve the objectives because controlling one thing also directly or indirectly influences some other things.

Third, a certification scheme should adopt the supply chain approach and consider the entire life cycle of biofuels and bioproducts. That is, a certification scheme needs to consider the sustainability of the entire biofuel and bioproduct supply chain and life cycle instead of only a segment of it, to maximize its efficacy. A biofuel and bioproduct certification scheme should also collaborate with and take advantage of existing certification programs for related products, to create synergistic effects and lower certification costs.

Fourth, a biofuel and bioproduct certification scheme should address domestic (including regional and national) concerns while seeking consistency in the certification standards with other major similar certification schemes in the world. This is important given the leading position of the US in the global production, trade,

Table 5 Selected major existing bioenergy certification schemes in different parts of the world

\begin{tabular}{|c|c|c|c|c|}
\hline Program/membership & $\begin{array}{l}\text { Type of bioenergy } \\
\text { certified }\end{array}$ & $\begin{array}{l}\text { Geographic } \\
\text { concentration }\end{array}$ & Current status & Members \\
\hline $\begin{array}{l}\text { Council on Sustainable Biomass Production } \\
\text { (CSBP) [64] }\end{array}$ & $\begin{array}{l}\text { Cellulosic biofuels and } \\
\text { feedstock }\end{array}$ & US (originally) & $\begin{array}{l}\text { Developed in 2012, never } \\
\text { implemented }\end{array}$ & $\begin{array}{l}\text { Meridian } \\
\text { institute }\end{array}$ \\
\hline $\begin{array}{l}\text { Roundtable on Sustainable Biomaterials } \\
\text { (RSB) [72] }\end{array}$ & All & Global & Implemented & $\begin{array}{l}\text { Multiple } \\
\text { stakeholders }^{a}\end{array}$ \\
\hline $\begin{array}{l}\text { International Sustainability and Carbon } \\
\text { Certification }(\text { ISCC })^{b}[73]\end{array}$ & All & Global & Implemented & $\begin{array}{l}\text { Multiple } \\
\text { stakeholders }\end{array}$ \\
\hline 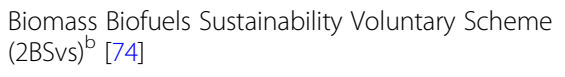 & All & Global & Implemented & $\begin{array}{l}\text { Multiple } \\
\text { stakeholders }\end{array}$ \\
\hline Roundtable on Sustainable Palm Oil (RSPO) ${ }^{\complement}$ [75] & Palm oil-based biofuels & Global & Implemented & $\begin{array}{l}\text { Multiple } \\
\text { stakeholders }\end{array}$ \\
\hline Bonsucro Production Standard (Bonsucro) ${ }^{c}$ [76] & $\begin{array}{l}\text { Sugarcane-based } \\
\text { biofuels }\end{array}$ & Global & Implemented & $\begin{array}{l}\text { Multiple } \\
\text { stakeholders }\end{array}$ \\
\hline Roundtable on Responsible Soy (RTRS) [77] & Soy-based biofuels & Global & Implemented & $\begin{array}{l}\text { Multiple } \\
\text { stakeholders }\end{array}$ \\
\hline
\end{tabular}

${ }^{a}$ Including a subset of businesses/industry, non-government organizations (NGOs), academics/research institutions, and government organizations

${ }^{b}$ Focusing on meeting the regulatory requirements of the EU Renewable Energy Directive (RED) [78]

${ }^{\mathrm{C}}$ Life-cycle assessment (LCA) greenhouse gas emissions have been included in a version of the system adapted to show compliance with the RED [78] 
and consumption of agricultural products and agriculture-based bioenergy products.

Fifth, a biofuel and bioproduct certification scheme should consider the participation of small farmers and biomass/bioenergy producers as well as large ones by developing mechanisms to lower participation costs for small farmers and producers or by application of riskbased approaches (Mansoor M, Stupak I, Smith CT et al.: Trust and Legitimacy in Sustainability Governance of Bioenergy Supply Chains, in preparation). In both cases, it is needed to engage with small farmers and producers, who are large in number and widely spread spatially. This would be essential to achieve the goals of the EISA of 2007 and to reap the overall benefits of biofuel and bioeconomic development.

\section{The role of markets and technology Markets}

Market forces and mechanisms can also play an important role in governing biofuel and bioproduct sustainability. The interaction of supply and demand yields the quantity of production and consumption, which ultimately determines socioeconomic and environmental impacts. Therefore, forces that drive supply and demand can also influence socioeconomic and environmental consequences. For instance, as discussed earlier, tax incentives or subsidies to biofuel producers or blenders shift the supply curve of biofuels, and biofuel production mandates, if fully implemented, can raise the output level of biofuels. Both can increase the quantity of biofuels produced and consumed, leading to associated socioeconomic and environmental impacts. Additionally, entities can exercise their market power (e.g., via market access, market size) to influence the setting and adoption of sustainability standards [80]. These principles have been well explained in the literature of economics, especially natural resource and environmental economics [81], and thus need not to be further elaborated here. Instead, we will discuss market interactions between biofuels and closely related products which have recently drawn heated debates on biofuel sustainability.

Energy is a ubiquitous product, consumed by all economic sectors and private consumers. Hence, as part of the overall energy market, biofuel markets interact with the markets of many other goods and services. Here, we focus our discussion on fuel, food, and fiber markets, which are most directly related to biofuel markets, and the implications of the market interactions for biofuel sustainability governance.

\section{Fuel markets}

Biofuels need to compete in the various energy markets (heat, power, transportation) with alternative energy sources. The production and prices of world and US oil markets have fluctuated tremendously over time. Recent development and applications of hydraulic fracturing (or fracking) technology have greatly improved the prospect of the US domestic oil supply, reduced oil prices, and even increased US oil exports (Fig. 5) [82]. As a result, the US national energy (oil) security concern has been eased to some extent. Meanwhile, fracking has yielded the abundant supply of natural gas in the US with an over 7-fold increase in gross natural gas withdrawals from shale gas from 2007 to 2016 [83], which can
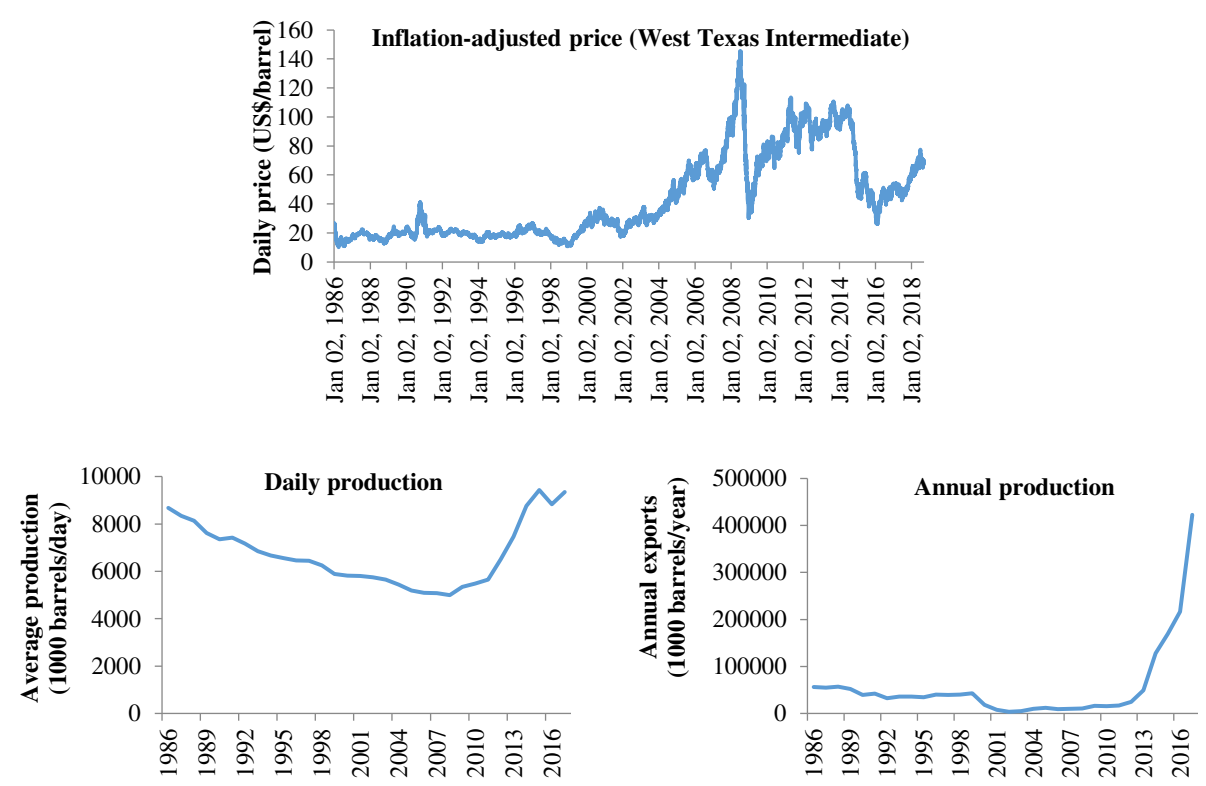

Fig. 5 US crude oil price, production, and exports [82] 
generate less GHG emissions when used to displace coal in heat and power generation.

In addition to the rising supply of domestic oil and natural gas, the US has witnessed a rapid increase in wind and solar energy production and consumption during the last decade (Fig. 6) [84]. By March 2017, wind and solar energy accounted for $8 \%$ and $2 \%$ of US electricity production, respectively, setting a historical record [85].

\section{Food markets}

Biofuel production and consumption can contribute to food price increases and volatility although many other factors such as economic and population growth and weather conditions are also attributable to food price changes. Biofuel production can impact the prices of both grain and animal products (e.g., meat and dairy products), and vice versa (Fig. 7), as economic theory suggests. Recent food vs. fuel debates have also pointed to the potential linkages between biofuel and food markets and expressed concerns about the implications of such linkages for food security [86]. For example, biofuel production can increase the prices of grains as some grains are used for biofuel production, and the production of some cellulosic feedstock (energy crops) competes with grain production for land. Similarly, biofuel production can increase the prices of feeds for livestock, thereby also affecting the prices of meat and dairy products.

Yet, precise empirical estimates of the impact of biofuel production on food prices remain challenging though extensive attempts have been made [87]. This is partly because food markets are related to many supply and demand factors, and it is extremely difficult to isolate the impact of biofuel production from others. A recent review and meta-analysis shows that there is a great deal of variation in the estimated impact of corn ethanol production on corn prices in the US and that, on average, corn prices would increase $3-4 \%$ for a one billion gallon (3.785 billion liters) increase in the US ethanol mandate in 2015 [88]. Corn ethanol production in the US was also found to amplify the corn price increase induced by the 2012 drought [89] and reduce the responsiveness of corn and food prices to export shocks [90]. These findings suggest that using corn for ethanol production in the US has raised corn prices and can influence corn price variations stemming from other factors like weather anomalies and market disruptions. Production of cellulosic and advanced biofuels, however, is expected to have a smaller effect on food prices than corn (grain) ethanol as residues rather than grain are used as feedstock [86]. Food price increases may have a mixed effect on food security as they raise both the cost for food buyers and the income for food producers including low-income farmers [91]. Regardless of the exact effect, this indicates the connectivity between the food and biofuel markets.

Connectivity between the ethanol market and the gasoline or corn market is also evidenced by ethanol prices being strongly correlated with gasoline and corn prices. The Pearson correlation coefficient between the quarterly prices of ethanol and gasoline and between the quarterly prices of ethanol and corn from 1982 to 2018 in the US is estimated to be 0.863 and 0.703 , respectively (Fig. 8), suggesting the gasoline, ethanol, and corn

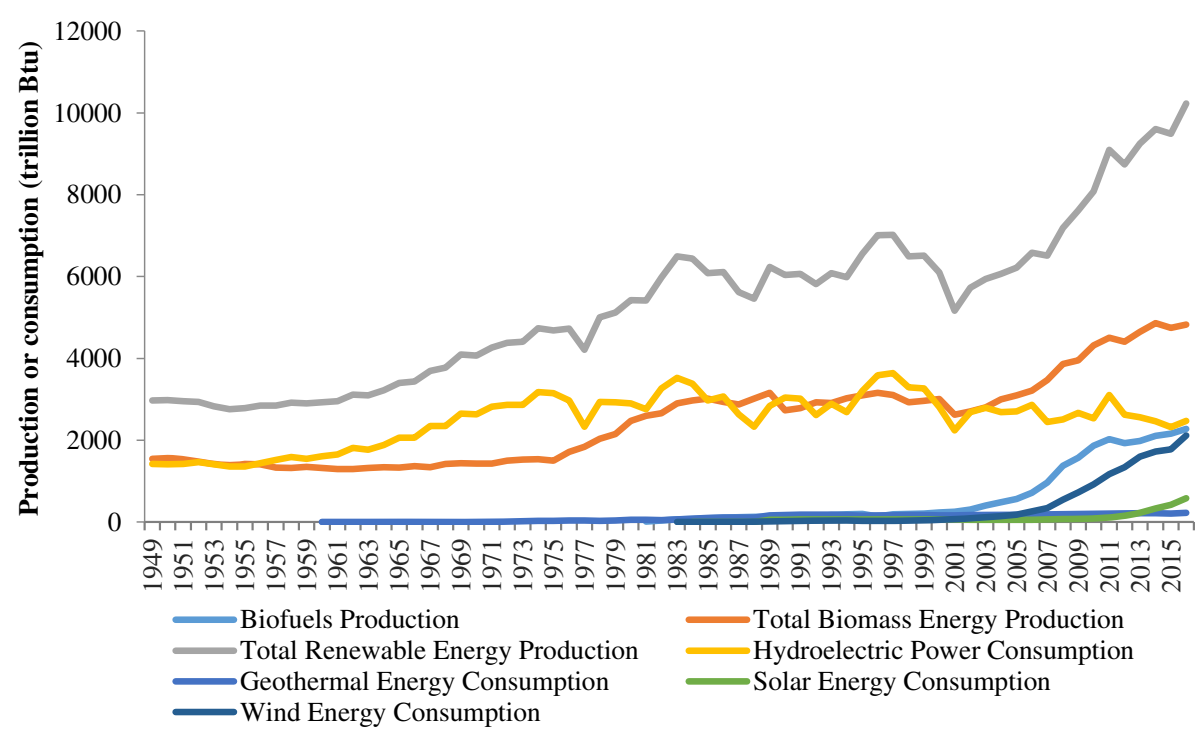

Fig. 6 Annual renewable energy production and consumption in the US [84] 


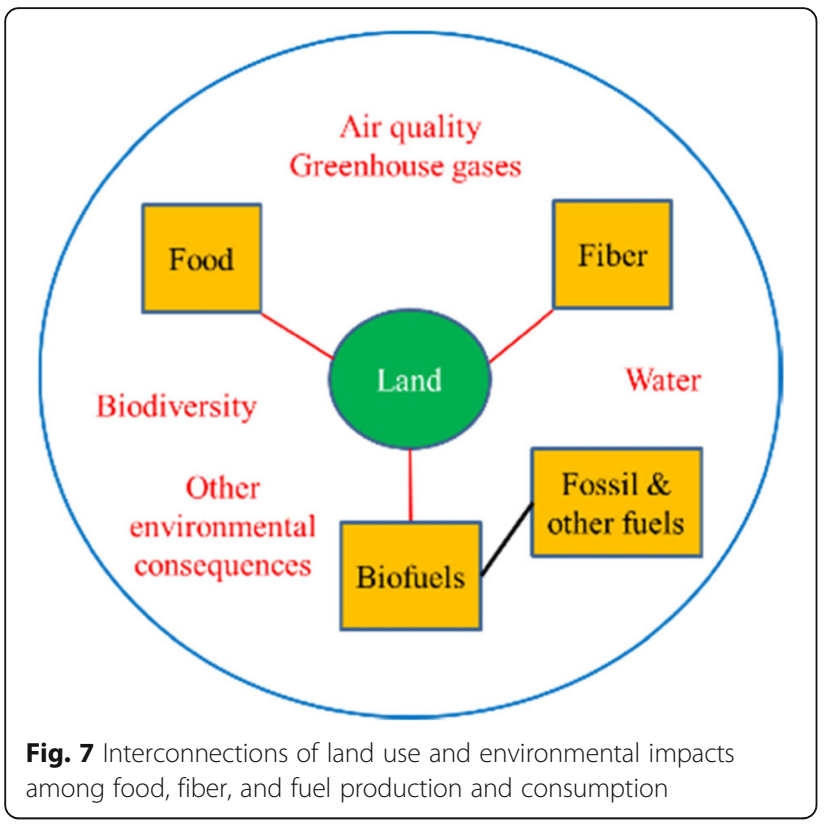

markets are synchronized. The linkages among corn, biofuel, and oil prices further reveal the connectivity among food, biofuel, and energy markets [92, 93].

\section{Fiber markets}

The possibility of land use competition between biofuel feedstock production and fiber production exists, although studies in this area are relatively few in agriculture (Fig. 7). A major agriculture-based fiber crop/plant is cotton. The potential link between biofuel and agriculture-based fiber is their likely competition for agricultural land. However, the likelihood of land use competition is unknown and appears to depend on local or regional conditions. This is partly because cotton is grown in a few regions, not as widely spread as grain crops and livestock, and as such land use competition with cotton has not been included in the national and global assessments of biofuel impacts. This, however, calls for more studies on the impacts of biofuel production at the local and regional levels as well as at the national and global levels.

\section{Land use and land use impacts}

Besides direct interactions among the food, fiber, and fuel markets (competition for raw materials), the interconnection among food, fiber, and biofuel production is also via their competition for land, as well as the joint environmental impacts of the land uses in the landscape (Fig. 7). The competition for land and the mitigation of environmental impacts can further be reflected in the market interactions (Fig. 7). For instance, land use competition may increase land cost, thereby boosting the prices of food, fiber, and biofuel products. Likewise, restriction and mitigation of soil erosion from food, fiber, and biofuel feedstock production may increase the production costs of these products. However, the magnitude of such market impacts would differ across food, fiber, and biofuel products, as well as spatially and over time.

The connection between biofuel and food markets suggests that the impact of biofuels (especially grain-based biofuels) on food security needs to be considered in sustainability monitoring and governance. Some of the world's largest biofuel producer countries like the US and Brazil are also among the largest exporting countries of food products (e.g., corn and soybean) [94]. Hence, biofuel development in these countries are likely to have an impact on the global markets of these food products, especially on smaller importing countries. Although international trade
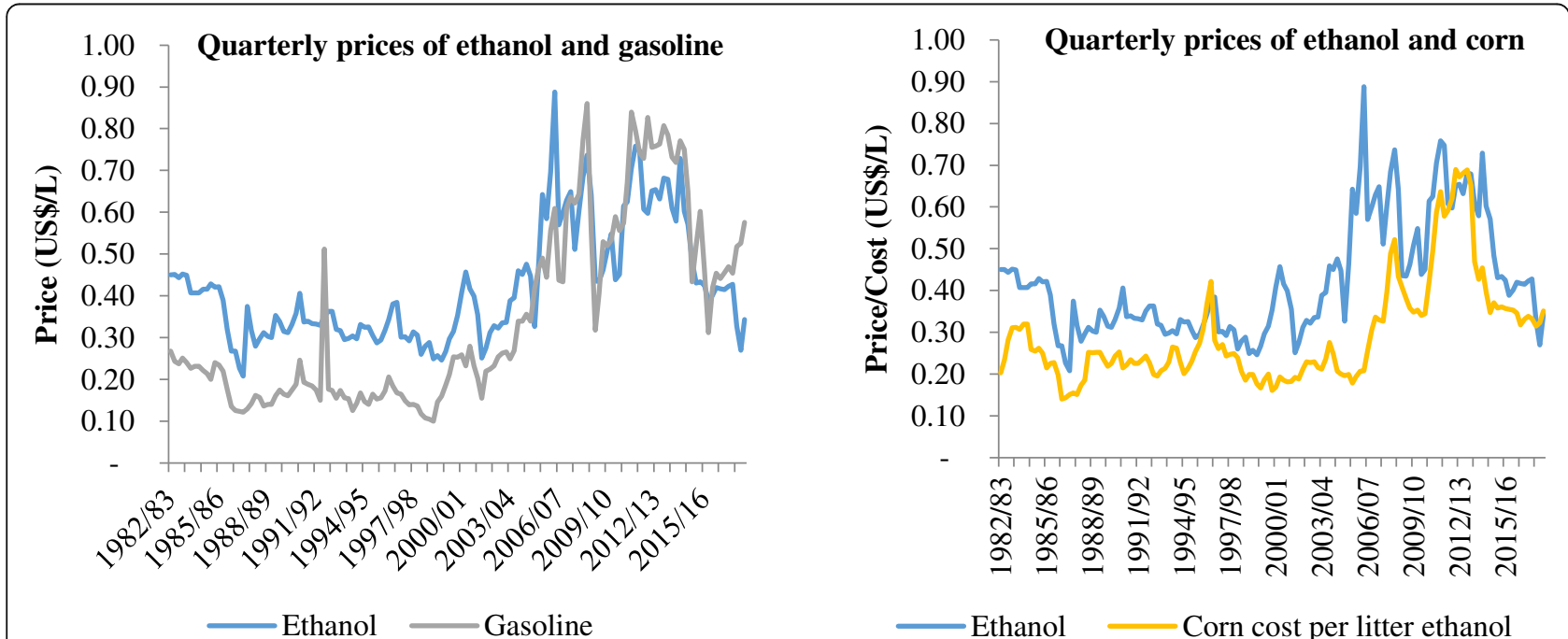

Fig. 8 Linkages among the quarterly prices of corn, ethanol, and oil [2] 
can take advantage of comparative advantages of individual countries, dramatic and rapid increases in food prices could make some countries more vulnerable in terms of affordable food supply, raising food security concerns and drive the conversion of non-agricultural land (including forest land) for crop and livestock production, increasing GHG emissions and degrading air and water quality and wildlife habitats [32, 33, 95, 96].

Compared to grain-based biofuels, development of cellulosic biofuels is likely to have less severe impacts on grain markets. Additionally, replacing grain-based biofuels with cellulosic biofuels can alleviate the competition between food and fuel. However, given the limited availability of marginal agricultural land, squeezing existing land use for growing energy crops can also increase the prices of some food products, including grain and animal products. For example, converting pasture land for bioenergy feedstock production could affect livestock production and the prices of livestock products. Additionally, collecting crop residues from existing cropland and converting existing less intensively used land to intensive biofuel feedstock production can elevate environmental concerns including GHG emissions and degradation of soil, water, and biodiversity $[38,44]$.

The linkages among food, fiber, biofuel, and energy markets indicate the complexity of biofuel sustainability governance and the importance of coordination among food, fiber, biofuel, and energy policies. International trade of food, fiber, and fuel products further intensifies the complex interlinkages among the production, consumption, and markets of these products, calling for a broad and effective coordination of sustainability governance. However, the delicate interlinkages also suggest that we do not have to monitor and control for everything in a sustainability governance system because when we have the measurements of some indicators, we may also know something about other indicators. Because food, fiber, and biofuel production all depends upon land and generates some joint environmental impacts, a sustainability governance system that addresses overarching issues associated with land use and the joint environmental impacts may be simpler and more effective than a separate system that specifically address the sustainability concerns resulting from producing each crop or product.

\section{Technology}

Technology can interact with laws and regulations, certification schemes, and market forces, and thus needs to be considered when developing and implementing a sustainability governance system. Here, we discuss a few technologies that have been used in conservation and/or have great potential and important implications for agriculture-based biofuel sustainability governance.

\section{Conservation tillage}

Conservation tillage including no-till and reduced tillage can help reduce soil erosion from agricultural lands and in some cases increase crop yields due to enhanced input use efficiency [97, 98]. Adopting conservation tillage can also mitigate soil erosion resulting from biomass harvest (e.g., corn residue collection and removals), so that more biomass (e.g., crop residues) can be harvested/removed from cropland without increasing soil erosion [99]. This is because soil erosion is directly related to biomass removal intensity.

Yet, conservation tillage, especially no-till, may increase the need for herbicide and other chemical use [100]. Farmers' willingness to adopt conservation tillage is also uncertain, and it may be especially challenging to convince them partly because they do not see the economic benefit of using conservation tillage [101].

\section{Genetically engineered crops for grain and bioenergy feedstock}

Genetically engineered (GE) crops, especially corn and soybean, have been widely adopted in the US. The most common GE crops in the US have been Bt (Bacillus thuringiensis, insect-resistant) and HT (herbicide-tolerant) crops, particularly those with both Bt and HT traits. Approximately $80 \%$ of the total corn area planted in the US in 2017 contained Bt, HT, or both traits (Fig. 9) [102].

Introduction of GE crops have benefits and risks $[103,104]$. As such, debates on whether GE crops for food or energy should be allowed will continue, precipitating the need and challenge for sustainability governance. On the one hand, advancements in plant biotechnology may reduce pesticide and herbicide use and the amount land needed to produce a given amount of food, fiber, and biofuel feedstock, thus alleviating the environmental impacts resulting from expanded and more intensive land management

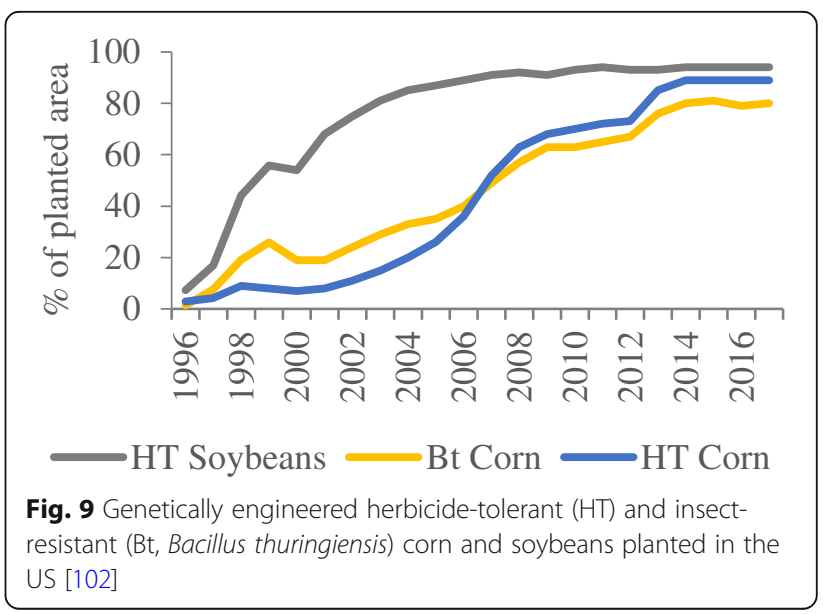


potentially caused by biofuel production. Additionally, HT corn has contributed to increased adoption of conservation tillage practices partly because of reduced herbicide need and more effective weed control [103]. On the other hand, there are concerns about the introduction of GE crops, mainly due to unknown or uncertain impacts on humans, other organisms, and the environment. Among the environmental risks is the evolution of resistance to transgenes and potential gene flows, transmission of transgenetic traits from GE crops to nearby plants and their wild relatives $[103,104]$.

Great opportunities of GE crops thus come with great risks or uncertainties [104]. Hence, development and adoption of GE crops have several implications for agriculture-based biofuel and bioeconomic development and associated sustainability governance. First, introduction of GE crops can increase biomass yields, reducing the need for agricultural land use expansion for feedstock production. Second, introduction of some GE crops (e.g., HT corn) can induce the adoption of conservation practices, increasing the residue harvest rate or reducing soil erosion and herbicide use while producing a same amount of biomass. Third, development of GE crops can alter the physical and chemical properties of biomass, so that they become better suited for the production of biofuels and other bioproducts. Fourth, the concerns about environmental risks and unknown impacts on human health are likely to add another dimension to developing and implementing biofuel sustainability governance systems as they are critical aspects of sustainability.

Overall, advancements in plant genetic technology can help reduce some environmental concerns associated with crop and biomass production, but meanwhile can create new environmental risks. Sustainability governance systems should take full advantages of positive benefits brought about by biotechnology advancements while monitoring and negating the uncertainties and harmful impacts of GE crops.

\section{Precision agriculture}

Currently there are three main precision agriculture (PA) technologies adopted by US farmers. They are Global Positioning System (GPS)-based tractor guidance systems, GPS soil and yield mapping, and variable-rate technology (VRT). These technologies help farmers adjust farming practices more precisely according to the information on field conditions collected by the devices. For example, they can lead to more precise application and management of farm inputs like seeds, fertilizers, herbicides, pesticides, and irrigation water. It is estimated that each of these technologies can contribute to a $1-3 \%$ increase in corn profits [105].
The specific functionalities and the ease of use vary across the technologies, which affect their adoption. Of these three technologies, yield monitoring/mapping is most widely used. Corn and large farmers are more likely to adopt these technologies. In 2010, yield monitors were used on $70 \%$ of planted corn acreage in the US, yield mapping on $44 \%$, soil mapping on $31 \%$, guidance systems on 54\%, and VRT on $28 \%$ [105].

These PA technologies can play a role in the sustainability governance of agriculture-based biomass feedstock production. More precise management of farm inputs (e.g., fertilizers, herbicides, and pesticides) reduces excess use of these inputs and associated negative environmental impacts. Additionally, because the sustainable harvest rate of crop residues depends upon field conditions and crop yield [37], these PA technologies can help farmers harvest a precise level of residues at a given location to meet both profitability and sustainability requirements.

The positive profit impact, though small, indicates the existence of some economic incentive for farmers, especially large farmers, to adopt these PA technologies. Yet, given the relatively low profit increase, there are still barriers to their wider adoption. For instance, the initial investment for these technologies is quite high, which may have prevented their adoption by small farmers and lowered the profitability. These barriers need to be removed in order to entice farmers to use the technologies and realize the associated economic and environmental benefits. Meanwhile, developing these technologies for biomass production could increase the utilization of the devices, potentially leading to a higher profit and increased environmental benefits.

The profit increase resulting from technology adoption, however, may not fully offset the associated costs especially for smaller farmers. This may hinder the expanded adoption of the PA technologies, undermining their potential contribution to sustainable management and governance except if other incentives are provided to the farmers to adopt the technology.

\section{Integrated biorefineries}

Integrated biorefineries use a suite of feedstock and processing technologies to produce a variety of bioproducts including biofuels and co-products. This technology, though still under development, is promising because it can more efficiently use feedstock and produce multiple products, reducing environmental impacts and enhancing profitability. The US has continued to invest on optimizing integrated biorefineries [25]. Adding value from non-fuel co-products, integrated biorefineries can foster commercial production of cellulosic biofuels [30].

Coupled with integrative biofuel supply chains, integrated biorefineries have several implications for sustainability and sustainability governance. First, the high efficiency of 
integrated biorefineries in terms of feedstock utilization and bioproduct production generates minimum environmental impacts and maximum economic benefits. Second, allowing for the combined use of different feedstock sources enhances land use efficiency, reducing pressure on land to produce a given amount of biofuels. Third, integrated biorefineries entail alternations of and integration with existing supply chains, providing an opportunity to build on and coordinate with existing sustainability monitoring and safeguard systems while the added complexity of new supply chains may create additional challenges for sustainability governance [106].

\section{Sustainability governance to induce behavioral change}

Sustainability governance can be defined as a set of regulatory processes and mechanisms initiated by either state or non-state actors that seek to create behavioral change and thus influence the actions and outcome of actions to make progress towards more sustainable conditions, based on defined sustainability criteria (Mansoor M, Stupak I, Smith CT et al.: Trust and Legitimacy in Sustainability Governance of Bioenergy Supply Chains, in preparation). It is thus crucial to understand which governance system can best induce the desired behavioral change.

Motivations for behavioral change include carrots, sticks, self-consciousness [107, 108], and social norms [109]. Sticks, or punishments, are often reflected in a mandatory system such as laws and regulations to punish for a bad behavior or a bad consequence from a behavior. Carrots can be incentives provided by a mandatory or voluntary program for a good behavior or a good consequence from a behavior. Additionally, incentives can be created or changed with market opportunities and technology advancements. Self-consciousness is an agent's self-awareness of responsibility for a good behavior or a good consequence of a behavior. Here, by definition, we consider self-consciousness independent of (not overlapping with) a stick or a carrot, although quite often behavior is influenced by a combination of stick, carrot, and self-consciousness. These three behavior-change motivations can be used as instruments for sustainability governance. Seeking their maximum synergies is essential to the efficacy of a sustainability governance system.
Both carrots and sticks are present in existing bioenergy sustainability governance systems. The carrots consist of tax breaks and other incentives for biomass and biofuel production, and the sticks include punishments for violations of laws (e.g., the CWA) or mandatory requirements with no compensation. The carrots are usually part of voluntary programs while the sticks are often associated with mandatory programs. Although the carrot and stick approach is functional to motivate behavior of individuals or organizations [108], the need and benefits to go beyond this approach by incorporating self-consciousness, trust, and social norms are evident [109], as it may reduce the need for incentives and control functions to obtain the desired behavior. This is also true for bioenergy sustainability governance (Mansoor M, Stupak I, Smith CT et al.: Trust and Legitimacy in Sustainability Governance of Bioenergy Supply Chains, in preparation).

Several types of sustainability governance systems exist, which can be seen as consisting of standards and participation requirements that each can be mandatory or voluntary, or both (Table 6). Entirely mandatory systems include laws and regulations even though some laws and regulations may not be fully enforced. Examples of entirely voluntary systems include, but are not limited to, best management practices and agents' self-initiated conservation activities.

Certification standards often consist of both mandatory (e.g., compliance with laws and regulations) and voluntary standards. Most of the conservation cost sharing or incentive programs have some pre-established standards that are required to be met if an agent chooses to participate in the program as well as some voluntary standards that are usually more flexible. This is also often the case for certification systems.

Compliance with laws and regulations is required for all, and participation is thus mandatory. On the other hand, participation in certification programs, conservation cost sharing or incentive programs, and BMPs is completely voluntary. Participation in voluntary programs may be motivated by the benefits arising from demonstration of compliance with these programs, self-consciousness of participants, or both. Agents (individuals or organizations) can also initiate their own conservation activities based on their self-consciousness and/or benefits.

Table 6 Current sustainability governance systems mix of mandatory and voluntary requirements

\begin{tabular}{|c|c|c|c|c|}
\hline \multirow[t]{2}{*}{ System/program } & \multicolumn{2}{|l|}{ Standard } & \multicolumn{2}{|c|}{ Participation requirement } \\
\hline & Mandatory & Voluntary & Mandatory & Voluntary \\
\hline Laws and regulations & $x$ & & $x$ & \\
\hline Sustainability certification programs & $x$ & $x$ & & $x$ \\
\hline Conservation incentive programs & $x$ & $x$ & & $x$ \\
\hline Best management practices & & $x$ & & $x$ \\
\hline Agent self-initiated conservation & & $x$ & & $x$ \\
\hline
\end{tabular}


Besides self-consciousness and the standards and requirements established in the mandatory and voluntary programs discussed above, social norms represent another set of standards or expectations for the behavior of individuals or organizations in society. The standards in the mandatory and voluntary programs and social norms are often mutually supplementary [110]. Additionally, compared to developing and implementing mandatory and voluntary programs, complying with social norms incurs relatively low transaction costs partly because it relies on self-compliance. While self-consciousness involves requirements that are internalized by the individual or the organization, social norms are not necessarily internalized. For example, self-compliance may be caused by fear of social or economic sanctions, or the expectations of social rewards, such as being part of formalized or informal communities.

One mechanism that can facilitate the internalization of social norms and sustainability governance requirements is corporate social responsibility (CSR). Corporations usually adjust their behavior in response to societal demands by first complying with legal requirements (obligation), then meeting social responsibilities (informal social norms), and finally surpassing the mainstream expectations (responsiveness) [111]. Although its definition varies, CSR, as practiced, often aims at considering environmental and social consequences while seeking profit maximization [112]. CSR often consists of self-consciousness, along with some pressure from society and embedded economic values (e.g., increased sales and profit resulting from the customers' positive perceptions about the environmental and social footprints of the products). Hence, CSR can be a viable element of a sustainability governance system.

\section{Recommendations for sustainability governance of biofuel and bioeconomic development in the US}

The above review clearly indicates the lack of current commercial production of cellulosic biofuels, existence of both potential for and concerns about commercial production of cellulosic biofuels, and availability of various existing sustainability governing instruments, though not specially designed and intended for biofuels, in the US. Based on these findings along with general sustainability governance principles and the lessons learned from previous bioenergy and other programs implemented in the US and other countries as discussed previously, we offer the following recommendations for governing biofuel and bioeconomic development in the US going forward.

\section{A governing framework for sustainability of biofuel and bioeconomic development}

It is evident that various instruments and mechanisms are available for sustainability governance. Many governing mechanisms and instruments can be complementary with one another. Moreover, to address a complex issue such as the sustainability governance of biofuel and bioeconomic development, any single instrument or mechanism alone is hardly adequate or effective. This is evidenced by previous similar endeavors including a recent global initiative to Reducing Emissions from Deforestation and forest Degradation (REDD+) $[113,114]$.

The connectivity among policy, regulation, certification, markets, technologies, social norms, and self-consciousness as regulators of behavior suggests that they all can play a role in the sustainability governance of agriculture-based biofuel and bioeconomic development. Hence, a sustainability governance system is expected to be more effective if it takes advantage of all these mechanisms to generate maximum synergistic effect on safeguarding sustainability. With this in mind, we propose a conceptual framework for developing a sustainability governance system for biofuel and bioeconomic development in the US, which includes several of these features (Fig. 10). It builds on existing policies and programs, mandatory and voluntary, and considers and leverages market and technology along with social norms and activities to internalize sustainability values and build self-consciousness. Finally, it adopts an adaptive feature to sustainability governance.

\section{Building on the existing system}

Compared to many other countries in the world, the US has a well-established sustainability governance system that is relevant to agriculture-based biofuel and bioeconomic development. This system consists of existing policies for agriculture, energy, natural resource management and conservation, and environment protection; natural resource and environmental monitoring systems; the legal system; and public awareness. This system, or combination of systems, can and should continue to play an important role in governing the sustainability of biofuel and bioeconomic development in the US.

In designing and implementing new governance policies and programs, existing policies and government and nongovernment programs within the different sectors need to be considered and incorporated. Drawing on existing policies and programs has several advantages. It can reduce transaction costs of sustainability governance by avoiding "reinventing the wheel." Also, it can more promptly detect and respond to the impacts covered by existing policies and programs, which represent most of the major environmental concerns associated with biofuel and bioeconomic development. Moreover, many existing policies and programs (e.g., the Clean Water Act and the Best Management Practices programs) are overarching regulations or programs intended to address some broad environmental issues caused by multiple activities including those that are beyond the specifics of biofuel and bioeconomic development. Relying on or strengthening the existing regulations and programs will enable the system to take a more 


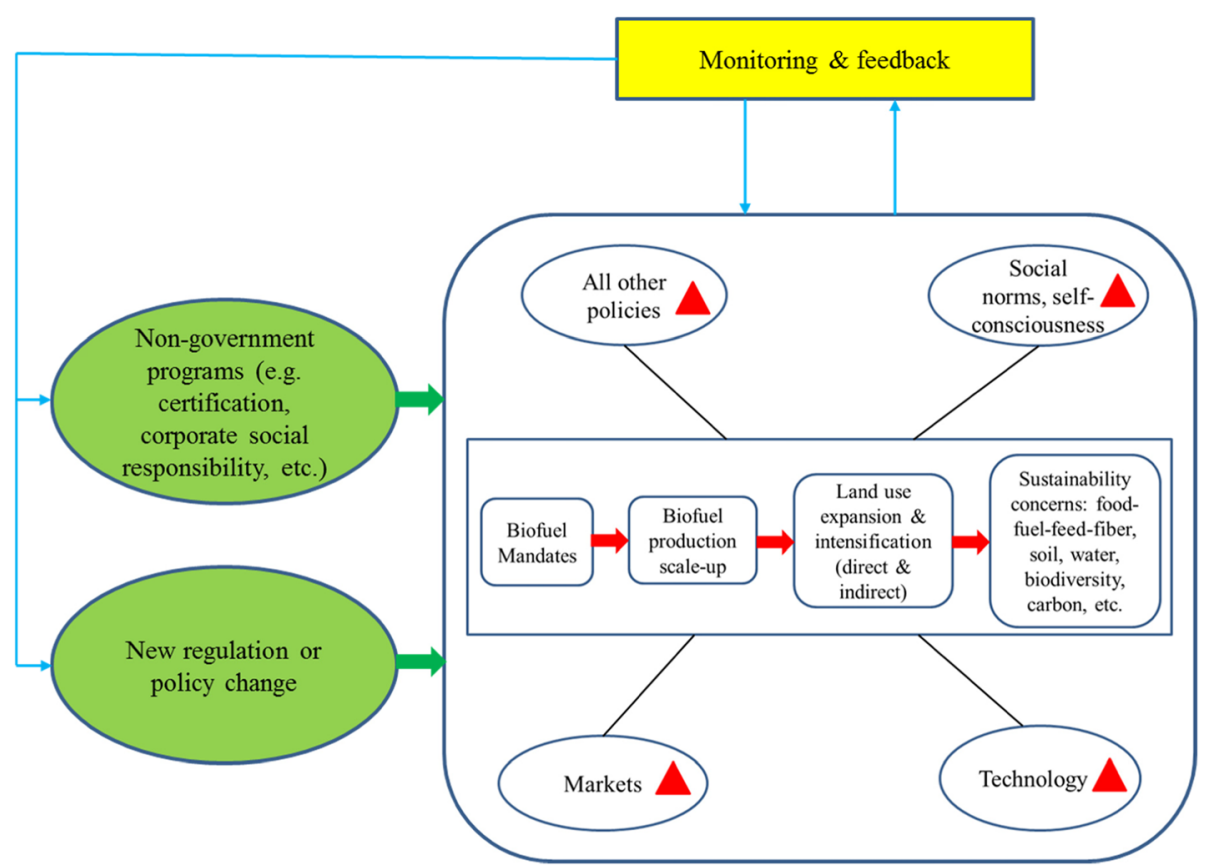

Fig. 10 Adaptive sustainability governance incorporating policy, certification, market, technology, social norms, and self-consciousness

holistic approach and thereby address common environmental concerns (e.g., soil, water, biodiversity) to which biofuel and bioeconomic development and many other activities all contribute.

However, existing regulations and programs may not be responsive to new or additional environmental and socioeconomic consequences resulting from biofuel and bioeconomic development, nor may they be effective to mitigate such impacts. For example, the Clean Air Act does not explicitly regulate to achieve GHG emission savings, which is an important driver for biofuel and bioeconomic development; some existing certification programs do not cover the entire biofuel supply chain and thus cannot safeguard the sustainability of biofuel production generally [106]. Additionally, domestic policies and programs are not able to control for the displaced impacts in other countries (e.g., indirect land use change), which can also in turn affect the US as the world becomes increasingly interconnected, economically and environmentally. All these cases suggest the need to modify existing policies and programs and/or add new ones.

\section{Considering and leveraging market and technology along with other forces}

As previously discussed, market and technology can play and have played important roles in shaping production and consumption, ultimately leading to environmental impacts. Thus, market, technology and their interactions need to be considered in addressing sustainability concerns associated with biofuel and bioeconomic development. Further, we showed that market and technology can be used as instruments or mechanisms for monitoring and mitigating negative impacts resulting from biofuel and bioeconomic development.

In terms of markets, this will first entail a good understanding of the links between the markets of biomass and biofuels and those of food, fiber, fossil fuel, and other renewable energy products. Such knowledge will help more effectively leverage market forces and mechanisms for sustainability governance. Subsequently, market-based approaches (e.g., tax, subsidy, market access) can be designed and adopted for sustainability governance. Market-based approaches can play a primary role or complement regulations in governing sustainability.

Regarding technology, it is critical to develop new technologies for more sustainable production, transport, and utilization of biomass, biofuels, and other bioproducts. Such technologies will reduce negative impacts in the first place, thus alleviating subsequent needs for mitigation efforts. Meanwhile, adopting more effective technologies for monitoring and mitigating negative impacts resulting from biofuel and bioeconomic development is also important. For instance, no-till and precision agriculture technologies can help reduce some environmental impacts associated with biomass production.

In addition to leveraging market and technology, social norms and levels of self-consciousness among organizations and individuals should be considered for the design of a sustainability governance system. Leveraging such forces may save resources, or activities aiming at 
increasing self-consciousness may be a part of the governance system. Several studies also show that the uptake of sustainability governance among the targeted actors, as well as willingness to comply with standards, depends on societal trust that it may take a long time to build [115]. Trust thus needs to be developed for policy and program design and enforcement aspects of governance systems to be legitimate in the eyes of the public and bioenergy sector actors. Advocating corporations to assume their social responsibilities should be another important part of the sustainability governance system.

\section{Adopting adaptive governance}

There are various sources of uncertainties associated with biofuel and bioeconomic development in the US. For instance, it is hard to predict when and to what extent the production of cellulosic biofuels will be scaled up in the US. There is also a lack of knowledge and data for understanding the interactions, especially higherorder interactions, within the biofuel production and consumption system and among the biofuel system, the broader socioeconomic system, and the environment. Given the fact that some uncertainty will always exist, adaptive sustainability governance seems appropriate. Such an approach should incorporate risk monitoring mechanisms and risk management strategies to safeguard biofuel and bioeconomic development from potential, especially irreversible, environmental risks. Monitoring systems should continually be improved so that governance mechanisms and strategies can be adjusted when new knowledge and information become available.

\section{Other recommendations for sustainability governance Overarching governance for land use and land-based resources management}

Land is a common resource base for food, fiber, and biofuel production, which generate some joint environmental impacts on soil, water, and wildlife habitats. Developing and implementing some overarching guidelines for land use and for the mitigation of these common environmental impacts caused by food, fiber, and biomass/biofuel production would be more effective to safeguard the overall sustainability of land-based resources than addressing these impacts resulting from food, fiber, or biofuel production, respectively. More integrative and coordinated land use planning and analysis would be helpful to improve land use efficiency and minimize the overall negative impacts of land use.

\section{Avoiding policy-induced unsustainability}

Sustainability concerns about production expansion of advanced and cellulosic biofuel production in the US stem from the biofuel mandates and production targets established in the regulation, i.e., the EISA of 2007. The conundrum is if and how any ex ante sustainability assessment was performed prior to the establishment of the production targets. Although an ex ante assessment might not anticipate, detect, or correctly assess all potential issues or concerns, it can help to avoid some of them. For this type of policy-induced unsustainability, a way forward is adjust the policy itself-for example, lowering the production target to a level that will not compromise sustainability goals other than climate change mitigation. However, it is a political task to make the possible tradeoffs.

\section{Keeping the governance system as simple as possible}

The broad scope and complex web of linkages associated with biofuel and bioeconomic development suggests the complexity of governing the associated sustainability concerns. Yet, an overly complex governance system is hardly feasible or effective. For example, when a governance system has too many indicators, it will be too costly, if not impossible, just to measure them, needless to say to control for the impacts measured by all these indicators. This does not mean that these indicators are not important, but instead suggests the need to further identify and quantify the relationships among some indicators. Knowledge about such relationships will help simplify sustainability monitoring and governance. Our analysis showed examples of existing linkages among the environmental, economic, and social aspects of biofuel and bioeconomic development. This indicates that a simpler sustainable governance system is also possible as the linkages imply that there is no need to control everything to achieve the sustainability objectives. Taking further advantages of these linkages will require more knowledge about the specific relationships among environmental, economic, and social indicators in the web around biofuel and bioeconomic development as well as aggregation and normalization of measurements of these indicators [116], when such knowledge is not already available. We suggest focusing on a few key indicators representing major sustainability concerns for an initial sustainability governance system, and then improving the system as new and better knowledge is obtained. Experiences from the biogas sector in Europe confirm that this may well be a useful way to move forward [117, 118].

\section{Conclusions}

Sustainability governance of agriculture-based biofuels and bioeconomic development is complex and challenging given the complexity of biofuel value chains and especially their interrelationships with the broader ecological, economic, and social systems, and other sectors such as food, fiber, and energy. Limited knowledge, lack of data, and uncertainties about the interrelationships add additional 
difficulty to designing an effective sustainability governance mechanism.

The complexity calls for a systematic approach to sustainability governance. However, a complex governance mechanism is impractical and costly and hence is unlikely to be adopted. Tractability entails a simple and yet effective mechanism. This is possible if we can understand and take advantage of the interrelationships among different components of the complex system. The interrelationships suggest that controlling for one thing will have impacts on others. Hence, there is no need to control for everything or all things to achieve the sustainability goals. Furthermore, strategic employment of sticks and carrots, and leverage of selfconsciousness and social norms in a sustainability governing system is of great importance to enhance its efficacy.

To move forward, we thus need to have a good understanding of the environmental, economic, and social impacts of biofuel and bioproduct production and consumption under various circumstances. Without such knowledge, it is impossible to effectively govern the sustainability of biofuel and bioeconomic development. Meanwhile, it is crucial to monitor biofuel and bioproduct development and deployment and key indicators for their associated environmental, economic, and social consequences. Fortunately, existing environmental regulations, increasing public awareness, and subsequent scrutiny of biofuel and bioproduct development have laid a strong foundation for biofuel and bioproduct sustainability governance in the US. Building on this foundation and proper monitoring, effective governing systems can be developed and implemented in response to sustainability impacts within the US when they arise in sync with gradual upscaling. However, one major challenge is likely to be indirect effects of US biofuel development on other parts of the world. How to govern biofuel sustainability at the global level, though extremely complex and important, is beyond the scope of this paper. This is a critical area for future studies.

\footnotetext{
Abbreviations

2BSvs: Biomass Biofuels Sustainability Voluntary Scheme; AMAP: Agriculture Management Assistance Program; BMP: Best management practice; Bt: Bacillus thuringiensis; CAA: Clean Air Act; CSBP: Council on Sustainable Biomass Production; CSP: Conservation Stewardship Program; CWA: The Clean Water Act; EISA: The Energy Independence and Security Act; EPA: Environmental Protection Agency; EQIP: Environmental Quality Incentives Program; ESA: The Endangered Species Act; FWS: Fish and Wildlife Service; GE: Genetically engineered; GHG: Greenhouse gas; GPS: Global Positioning System; HT: Herbicide-tolerant; IEA: International Energy Agency; ILUC: Indirect land use change; ISCC: International Sustainability and Carbon Certification; LCA: Life-cycle assessment; LCl: Landscape Conservation Incentives; NAAQS: National Ambient Air Quality Standards; NGO: NonGovernmental Organization; NOAA: National Oceanic and Atmospheric Administration; NRCS: Natural Resources Conservation Service; PA: Precision agriculture; REDD+: Reducing Emissions from Deforestation and forest Degradation; RSB: Roundtable on Sustainable Biomaterials; RSPO: Roundtable
}

on Sustainable Palm Oil; RTRS: Roundtable on Responsible Soy; SWRCA: The Soil and Water Resources Conservation Act; USDA: US Department of Agriculture; VRT: Variable-rate technology

\section{Acknowledgements}

The authors would like to thank IEA Bioenergy, also known as the Technology Collaboration Programme (TCP) for a Programme of Research, Development and Demonstration on Bioenergy, for funding under the IEA Bioenergy inter-task project "Measuring, governing and gaining support for sustainable bioenergy supply chains." We also wish to thank the participants of the 2018 International Conference on Governing Sustainability of Bioenergy, Biomaterial and Bioproduct Supply Chains from Forest and Agricultural Landscapes held in Copenhagen, Denmark, and the 2017 IEA

Bioenergy's Sustainability of Bioenergy Supply Chains Workshop held in Gothenburg, Sweden, for their helpful comments on the preliminary presentations of the outcomes of this study. For more information, see http://itpsustainable.ieabioenergy.com/. The views, findings, and publications of IEA Bioenergy do not necessarily represent the views or policies of the IEA Secretariat or its individual member countries.

\section{Authors' contributions}

JG designed and carried out the study and wrote the first draft of the manuscript. IS and CTS contributed to the study design. All authors wrote, read, and approved the final manuscript.

\section{Funding}

This study was partially funded by International Energy Agency (IEA) Bioenergy. The authors also acknowledge the support from Texas A\&M University (USA), the University of Copenhagen (Denmark), and the University of Toronto (Canada) to their participation in this project. However, the authors are solely responsible for the design, implementation, and findings of this study as well as the opinions expressed here.

Availability of data and materials

All data generated or analyzed during this study are included in this article.

Ethics approval and consent to participate

Not applicable

\section{Consent for publication}

Not applicable

\section{Competing interests}

The authors declare that they have no competing interests.

\section{Author details}

${ }^{1}$ Department of Ecosystem Science and Management, Texas A\&M University, College Station, TX 77843, USA. ${ }^{2}$ Department of Geosciences and Natural Resource Management (IGN), University of Copenhagen, Copenhagen, Denmark. ${ }^{3}$ University of Toronto, Toronto, ON M5S 3B3, Canada.

Received: 19 November 2018 Accepted: 1 October 2019

Published online: 12 December 2019

\section{References}

1. Bacovsky D, Ludwiczek N, Pointner C, Verma VK (2016) IEA Bioenergy countries' report - Bioenergy policies and status of implementation. https:// www.ieabioenergy.com/wp-content/uploads/2016/09/iea-bioenergycountries-report-13-01-2017.pdf. Accessed 17 July 2018.

2. US Department of Agriculture Economic Research Service (USDA ERS) (2018a) US bioenergy statistics. https://www.ers.usda.gov/data-products/usbioenergy-statistics/. Accessed 25 Sept 2018.

3. Pimentel D (2003) Ethanol fuels: energy balance, economics, and environmental impacts are negative. Nat Resour Res 12(2):127-134 https:// doi.org/10.1023/A:1024214812527

4. US Congress (2007) Energy Independence and Security Act of 2007. Public Law No: 110-140. The 110th Congress, Washington, DC.

5. US Department of Energy (USDOE) (2016) 2016 Billion-ton report: advancing domestic resources for a thriving bioeconomy, vol 1: economic availability of feedstocks. Langholtz MH, Stokes BJ, Eaton LM (Leads), ORNL/TM-2016/ 160. Oak Ridge National Laboratory, Oak Ridge, TN. doi: https://doi.org/10. 
2172/1271651. http://energy.gov/eere/bioenergy/2016-billion-ton-report. Accessed 23 Apr 2018.

6. Committee on Economic and Environmental Impacts of Increasing Biofuels Production of the National Research Council (2011) Renewable fuel standard: potential economic and environmental effects of US biofuel policy. National Academies Press, Washington, DC

7. US Congress (1970) Clean Air Act of 1970. Public Law No: 91-604. The 91st Congress, Washington, DC

8. US Congress (1990) Clean Air Act Amendments of 1990. Public Law No: 101-549. The 101st Congress, Washington, DC.

9. US Congress (1978) Energy Tax Act of 1978. Public Law No: 95-618. The 95th Congress, Washington, DC.

10. US Congress (1982) Surface Transportation Assistance Act of 1982. Public Law No: 97-424. The 97th Congress, Washington, DC.

11. US Congress (1984) Deficit Reduction Act of 1984. Public Law No: 998-369. The 98th Congress, Washington, DC.

12. US Congress (1990) Omnibus Budget Reconciliation Act of 1990. Public Law No: 101-508. The 101st Congress, Washington, DC.

13. US Congress (1992) Energy Policy Act of 1992. Public Law No: 102-486. The 102nd Congress, Washington, DC.

14. US Congress (1998) Transportation Equity Act for the 21st Century of 1998 Public Law No: 105-178. The 105th Congress, Washington, DC.

15. US Congress (2004) Job Creation Act of 2004. Public Law No: 108-357. The 108th Congress, Washington, DC.

16. US Congress (2005) Energy Policy Act of 2005. Public Law No: 109-58. The 109th Congress, Washington, DC.

17. US Congress (2008) Energy Improvement and Extension Act of 2008. Public Law No: 110-343. The 110th Congress, Washington, DC.

18. US Congress (2008) Food, Conservation, and Energy Act of 2008. Public Law No: 110-234. The 110th Congress, Washington, DC.

19. US Congress (2010) Tax Relief, Unemployment Insurance Reauthorization, and Job Creation Act of 2010. Public Law No: 111-312. The 111th Congress, Washington, DC.

20. US Congress (2012) American Taxpayer Relief Act of 2012. Public Law No: 112-240. The 112th Congress, Washington, DC.

21. US Congress (2014) Tax Increase Prevention Act of 2014. Public Law No: 113-295. The 113th Congress, Washington, DC.

22. US Congress (2014) Agricultural Act of 2014. Public Law No: 113-79. The 113th Congress, Washington, DC.

23. US Congress (2016) Consolidated Appropriations Act of 2016. Public Law No: 114-113. The 114th Congress, Washington, DC

24. Hochman G, Traux M, Zilberman D (2017) US biofuel policies and markets. In: Khanna M, Zilberman D (eds) Handbook of bioenergy economics and policy, vol II - natural resource management and policy 40 . Springer International Publishing AG, Cham, Switzerland

25. USDOE (2018) Bioenergy research and development. https://www.energy. gov/eere/bioenergy/research-and-development. Accessed 25 Sept 2018.

26. USDA ERS (2018b) Major land use. https://www.ers.usda.gov/data-products/ major-land-uses/major-land-uses/\#Summary\%20tables. Accessed 12 Apr 2018.

27. US Department of Agriculture National Agricultural Statistics (USDA NAS) (2018) Quick statistics. https://quickstats.nass.usda.gov. Accessed 25 Sept 2018.

28. Nair SK, Hartley DS, Gardner TA, McNunn G (2017) Searcy EM (2017) An integrated landscape management approach to sustainable bioenergy production. Bioenerg Res 10:929-948. https://doi.org/10.1007/s12155-017-9854-3

29. Nair SK, Griffel LM, Hartley DS, McNunn GS, Kunz MR (2018) Investigating the efficacy of integrating energy crops into non-profitable subfields in lowa. BioEnerg Res 11:623-637 https://doi.org/10.1007/s12155-018-9925-0

30. Chen M, Smith PM (2017) The U.S. cellulosic biofuels industry: expert views on commercialization drivers and barriers. Biomass Bioenergy 102:52-61

31. Swinton SM, Babcock BA, James LK, Bandaru V (2011) Higher US crop prices trigger little area expansion so marginal land for biofuel crops is limited. Energ Policy 39:5254-5258 https://doi.org/10.1016/j.enpol.2011.05.039

32. Searchinger T, Heimlich R, Houghton RA, Dong F, Elobeid A, Fabiosa J, Tokgoz S, Hayes D, Yu T-H (2008) Use of US croplands for biofuels increases greenhouse gases through emissions from land-use change. Science 319(5867):1238-1240. https://doi.org/10.1126/science.1151861

33. Fargione J, Hill J, Tilman D, Polasky S, Hawthorne P (2008) Land clearing and the biofuel carbon debt. Science 319(5867):1235-1238. https://doi.org/10. 1126/science.1152747

34. Ahlgren S, Di Lucia L (2014) Indirect land use changes of biofuel production - a review of modelling efforts and policy developments in the European Union. Biotechnol Biofuels 7:35 https://doi.org/10.1186/1754-6834-7-35
35. Gan J, Smith CT (2011) Optimal plant size and feedstock supply radius: a modeling approach to minimize bioenergy production costs. Biomass Bioenergy 35:3350-3359 https://doi.org/10.1016/j.biombioe.2010.08.062

36. Golecha R, Gan J (2016) Effects of corn stover year-to-year supply variability and market structure on biomass utilization and cost. Renew Sust Energ Rev 57:34-44 https://doi.org/10.1016/j.rser.2015.12.075

37. Gan J, Langeveld JWA, Smith CT (2014) An agent-based modeling approach for determining corn stover removal rate and transboundary effects. Environ Manag 53:333-342 https://doi.org/10.1007/s00267-013-0208-4

38. Hoekman SK, Broch A (2018) Environmental implications of higher ethanol production and use in the US: a literature review, part II - biodiversity, land use change, GHG emissions, and sustainability. Renew Sust Energ Rev 81: 3159-3177 https://doi.org/10.1016/j.rser.2017.05.052

39. Zilberman D (2017) Indirect land use change: much ado about (almost) nothing. GCB Bioenergy 9:485-488 https://doi.org/10.1111/gcbb.12368

40. Kline KL, Msangi S, Dale VH, Woods J, Souza GM, Osseweijer P, Clancy JS, Hilberg JA, Johnson FX, McDonnell PC, Mugera HK (2017) Reconciling food security and bioenergy: priorities for action. GCB Bioenergy 9:557-576. https://doi.org/10.1111/gcbb.12366

41. Williams PRD, Inman D, Aden A, Heath GA (2009) Environmental and sustainability factors associated with next-generation biofuels in the US: what do we really know? Environ Sci Technol 43(13):4763-4775. https://doi. org/10.1021/es900250d

42. Wilhelm WW, Johnson JMF, Karlen DL, Lightle DT (2007) Corn stover to sustain soil organic carbon further constrains biomass supply. Agron J 99: 1665-1667. https://doi.org/10.2134/agronj2007.0150

43. Sheehan J, Aden A, Paustian K, Killian K, Brenner J, Walsh M, Nelson R (2004) Energy and environmental aspects of using corn stover for fuel ethanol. J Ind Ecol 7:117-146 https://doi.org/10.1162/108819803323059433

44. Hoekman SK, Broch A, Liu X (2018) Environmental implications of higher ethanol production and use in the US: a literature review, part I - impacts on water, soil, and air quality. Renew Sust Energ Rev 81:3140-3158 https:// doi.org/10.1016/j.rser.2017.05.050

45. National Research Council (2008) Water implications of biofuels production in the US. The National Academies Press, Washington, DC

46. Dieter CA, Maupin MA, Caldwell RR, Harris MA, Ivahnenko TI, Lovelace JK, Barber NL, Linsey KS (2018) Estimated use of water in the United States in 2015. US Geological Survey Circular 1441. https://doi.org/10.3133/cir1441.

47. Lal R (2006) Soil and environmental implications of using crop residues as biofuel feedstock. Int Sugar J 108:161-167

48. Pellegrino J, Antes M, Zotter B, Andres H, Scher C (2007) Water impacts from increased biofuels production: an analysis of water issues based on future feedstock production scenarios. National Renewable Energy Laboratory, Golden, CO.

49. Powers SE (2005) Quantifying cradle-to-farm gate life-cycle impacts associated with fertilizer used for corn, soybean, and stover production. National Renewable Energy Laboratory, Golden, CO.

50. Werling BP, Dickson TL, Isaacs R, Gaines H, Gratton C, Gross KL, Liere H, Malmstrom CM, Meehan TD, Ruan L, Robertson BA, Robertson GP, Schmidt TM, Schrotenboer AC, Teal TK, Wilson JK, Landis DA (2014) Perennial grasslands enhance biodiversity and multiple ecosystem services in bioenergy landscapes. PNAS 111(4):1652-1657. https://doi.org/10.1073/pnas. 1309492111

51. Langpap C, Wu J (2011) Potential environmental impacts of increased reliance on corn-based bioenergy. Environ Resour Econ 49(2):147-171 https://doi.org/10.1007/s10640-010-9428-8

52. Dale VH, Kline KL, Richard TL, Karlen DL, Belden WW (2018) Bridging biofuel sustainability indicators and ecosystem services through stakeholder engagement. Biomass Bioenergy 114:143-156 https://doi.org/10.1016/.biombioe.2017.09.016

53. Hill J, Nelson E, Tilman D, Polasky S, Tiffany D (2006) Environmental, economic, and energetic costs and benefits of biodiesel and ethanol biofuels. PNAS 103(30):11206-11210 https://doi.org/10.1073/pnas. 0604600103

54. Groom MJ, Gray EM, Townsend PA (2008) Biofuels and biodiversity: principles for creating better policies for biofuel production. Conserv Biol 22:602-609. https://doi.org/10.1111/j.1523-1739.2007.00879.x

55. Robertson GP, Dale VH, Doering OC, Hamburg SP, Melillo JM, Wander MM, Parton WJ, Adler PR, Barney JN, Cruse RM, Duke CS, Fearnside PM, Follett RF, Gibbs HK, Goldemberg J, Mladenoff DJ, Ojima D, Palmer MW, Sharpley A, Wallace L, Weathers KC, Wiens JA, Wilhelm WW (2008) Sustainable biofuels redux. Science 322(5898):49-50. https://doi.org/10.1126/science.1161525 
56. Sims RH, Hastings A, Schlamadinger B, Taylor G, Smith P (2006) Energy crops: current status and future prospects. Glob Chang Biol 12:2054-2076 https://doi.org/10.1111/j.1365-2486.2006.01163.x

57. Heaton EA, Dohleman FG, Long SP (2008) Meeting US biofuel goals with less land: the potential of Miscanthus. Glob Chang Biol 14:2000-2014 https://doi.org/10.1111/j.1365-2486.2008.01662.x

58. DiTomaso JM, Barney JN, Fox AM (2007) Biofuel feedstocks: the risk of future invasions. CAST, Ames, IA

59. Lewandowski I, Scurlock JMO, Lindvall E, Christou M (2003) The development and current status of perennial rhizomatous grasses as energy crops in the US and Europe. Biomass Bioenergy 25:335-361 https://doi.org/ 10.1016/S0961-9534(03)00030-8

60. McLaughlin SB, De La Torre Ugarte DG, Garten CT Jr, Lynd LR, Sanderson MA, Tolbert VR, Wolf DD (2002) High-value renewable energy from prairie grasses. Environ Sci Technol 36:2122-2129. https://doi.org/10.1021/es010963d

61. Junginger M, Faigg A, Rosillo-Calle F, Wood J (2006) The growing role of biofuels -opportunities, challenges, and pitfalls. Int Sugar J 108:618-629

62. US Department of Agriculture Natural Resources Conservation Service (USDA NRCS) (2018) Programs. https://www.nrcs.usda.gov/wps/portal/nrcs/ main/national/programs/. Accessed 17 Apr 2018.

63. Logan TJ (1993) Agricultural best management practices for water pollution control: current issues. Agric Ecosyst Environ 46(1-4):223-231 https://doi.org/ 10.1016/0167-8809(93)90026-L

64. Council on Sustainable Biomass Production. http://www.merid.org/Content/ Projects/Council_on_Sustainable_Biomass_Production.aspx. Accessed 9 Oct 2018.

65. US Congress (1972) Federal Water Pollution Control Act Amendments of 1972. Public Law No: 92-500. The 92nd Congress, Washington, DC.

66. US Congress (1973) Endangered Species Act of 1973. Public Law No: 93-205. The 93rd Congress, Washington, DC.

67. US Congress (1977) Soil and Water Resources Conservation Act of 1977. Public Law No: 95-192. The 95th Congress, Washington, DC

68. USDA NRCS (2017) RCA report - interactive data viewer. https://www.nrcs.usda. gov/wps/portal/nrcs/rca/national/technical/nra/rca/ida/. Accessed 2 July 2018.

69. Cashore B (2002) Legitimacy and the privatization of environmental governance: how non-state market-driven (NSMD) governance systems gain rule-making authority. Governance: Int J Policy Admin Inst 15(4):503-529 https://doi.org/10.1111/1468-0491.00199

70. Pelkmans L, Goovaerts L, Stupak I, Smith CT, Goh CS, Junginger M, Chum H, Eng AG, Cowie A, Englund A, Joudrey J, Dahlman L (2013) Monitoring sustainability certification of bioenergy - short summary. IEA Bioenergy, Paris. http://www.ieabioenergy.com/wp-content/uploads/2013/10/ Monitoring-Sustainability-Certification-of-Bioenergy-Short-summary.pdf. Accessed 3 May 2018.

71. Stupak I, Joudrey J, Smith CT, Pelkmans L, Chum H, Cowie A, Englund O, Goh CS, Junginger M (2016) A global survey of stakeholder views and experiences for systems needed to effectively and efficiently govern sustainability of bioenergy. WIRES Energ Environ 5:89-118. https://doi.org/10.1002/wene.166

72. Roundtable on Sustainable Biomaterials. https://rsb.org/certification/. Accessed 9 Oct 2018.

73. International Sustainability and Carbon Certification. https://www.isccsystem.org/. Accessed 9 Oct 2018.

74. Biomass Biofuels Sustainability Voluntary Scheme. https://www.2bsvs.org/lg_ en.html. Accessed 9 Oct 2018.

75. Roundtable on Sustainable Palm Oil. https://www.rspo.org/certification. Accessed 9 Oct 2018.

76. Bonsucro Production Standard. https://www.bonsucro.com/productionstandard/. Accessed 9 Oct 2018.

77. Roundtable on Responsible Soy. http://www.responsiblesoy.org/ certification/nuestra-certificacion/?lang=en. Accessed 9 Oct 2018.

78. The European Parliament and the Council of the European Union (2009) Directive 2009/28/EC of the European Parliament and of the Council of 23 April 2009 on the promotion of the use of energy from renewable sources and amending and subsequently repealing Directives 2001/77/EC and 2003/30/EC. https://eur-lex.europa.eu/legal-content/EN/ALL/?uri=CELEX:32 009L0028. Accessed 2 Nov 2018.

79. The Natural Resources Defense Council (2014) Biofuel sustainability performance guidelines. NRDC Report 14-04-A. https://www.nrdc.org/sites/default/files/ biofuels-sustainability-certification-report.pdf. Accessed 3 May 2018.

80. Renckens S, Skogstad G, Mondou M (2017) When normative and market power interact: The European Union and global biofuels governance. J Common Mark Stud 55(6):1432-1448 https://doi.org/10.1111/jcms.12584
81. Tietenberg $T$, Lewis $L$ (2018) Environmental and natural resource economics, 11 th edn. Routledge, Abingdon, UK

82. US Energy Information Administration (USEIA) (2018a) Petroleum and other liquids. https://www.eia.gov/petroleum/data.php. Accessed 10 July 2018.

83. USEIA (2018b) US natural gas gross withdrawals from shale gas. https://www. eia.gov/dnav/ng/hist/ngm epg0 fgs nus mmcfa.htm. Accessed 10 July 2018.

84. USEIA (2018c) Total energy. https://www.eia.gov/totalenergy/data/browser/?tbl= T10.01\#/?f=A\&start=1949\&end=2016\&charted=6-7-8-9-14. Accessed 10 July 2018.

85. USEIA (2017) Today in energy. https://www.eia.gov/todayinenergy/detail. php?id=31632\#. Accessed 10 July 2018.

86. Tenenbaum DJ (2008) Food vs. fuel: diversion of crops could cause more hunger Environ Health Perspect 116(6):A254-A257. https://doi.org/10.1289/ehp.116-a254

87. Zilberman D, Hochmann G, Rajagopal D, Sexton S, Timilsina G (2013) The impact of biofuels on commodity food prices: assessment of findings. Am J Agric Econ 95(2):275-281 https://doi.org/10.1093/ajae/aas037

88. Condon N, Klemick H, Ann Wolverton A (2015) Impacts of ethanol policy on corn prices: a review and meta-analysis of recent evidence. Food Policy 51: 63-73 https://doi.org/10.1016/j.foodpol.2014.12.007

89. Carter C, Rausser GC, Smith A (2012) The effect of the US ethanol mandate on corn prices. Unpublished manuscript. http://www.ourenergypolicy.org/ wp-content/uploads/2013/07/The-Effect-oftheUS-Ethanol-Mandate-on-CornPrices-.pdf. Accessed 5 Apr 2018.

90. Drabik D, Ciaian P, Pokrivčák J (2016) The effect of ethanol policies on the vertical price transmission in corn and food markets. Energy Econ 55:189199 https://doi.org/10.1016/j.eneco.2016.02.010

91. Swinnen J, Squicciarini P (2012) Mixed messages on prices and food security. Science 335(6067):405-406. https://doi.org/10.1126/science.1210806

92. de Gorter H, Drabik D, Just DR (2013) How biofuels policies affect the level of grains and oilseed prices: theory, models and evidence. Global Food Secur 2(2):82-88 https://doi.org/10.1016/j.gfs.2013.04.005

93. Wisner R (2014) Ethanol, gasoline, crude oil and corn prices: are the relationships changing? https:/www.agmrc.org/renewable-energy/ethanol/ethanol-gasolinecrude-oil-and-corn-prices-are-the-relationships-changing/. Accessed 21 July 2018.

94. Food and Agriculture Organization of the United Nations (2018) FAOSTAT. http://www.fao.org/faostat/en/\#data. Accessed 10 July 2018.

95. Campbell A, Doswald N (2009) The impacts of biofuel production on biodiversity: a review of the current literature. UNEP-WCMC, Cambridge, UK https://www.cbd.int/agriculture/2011-121/UNEP-WCMC3-sep11-en.pdf. Accessed 23 June 2018

96. Fargione J, Plevin R, Hill J (2010) The ecological impact of biofuels. Annu Rev Ecol Evol S 41:351-377 https://doi.org/10.1146/annurev-ecolsys-102209-144720

97. Anderson RL (2011) Synergism: a rotation effect of improved growth efficiency. In: Sparks DL (ed) Advances in agronomy, vol 112. Academic Press, Cambridge, MA

98. Busari M, Kukal S, Kaur A, Bhatt R, Dulazi A (2015) Conservation tillage impacts on soil, crop and the environment. Int Soil Water Conserv Res 3(2): 119-129 https://doi.org/10.1016/j.iswcr.2015.05.002

99. Johnson J, Novak J (2012) Chapter 8 - sustainable bioenergy feedstock production systems: integrating carbon dynamics, erosion, water quality, and greenhouse gas production. In: Liebig MA, Franzluebbers AJ, Follett RF (eds) Managing agricultural greenhouse gases. Academic Press, San Diego, CA

100. Day JC, Hallahan CB, Sandretto CL, Lindamood WA (1999) Pesticide use in US corn production: does conservation tillage make a difference? J Soil Water Conserv 54(2):477-484

101. Andrews AC, Clawson RA, Gramig BM, Raymond L (2013) Why do farmers adopt conservation tillage? An experimental investigation of framing effects. J Soil Water Conserv 68(6):501-511. https://doi.org/10.2489/jswc.68.6.501

102. USDA ERS (2018c) Adoption of genetically engineered crops in the United States, 1996-2017. https://www.ers.usda.gov/webdocs/charts/58020/ biotechcrops_d.html?v=42565. Accessed 12 Apr 2018.

103. Gewin V (2003) Genetically modified corn - environmental benefits and risks. PLoS Biol 1(1):e8 https://doi.org/10.1371/journal.pbio.0000008

104. Wolfenbarger $L$, Phifer $P$ (2000) The ecological risks and benefits of genetically engineered plants. Science 290(5499):2088-2093. https://doi.org/ 10.1126/science. 290.5499 .2088

105. Schimmelpfennig D (2016) Farm profits and adoption of precision agriculture. ERR-217. US Department of Agriculture Economic Research Service, Washington, DC

106. Gan J, Cashore B (2013) Opportunities and challenges for integrating bioenergy into sustainable forest management certification programs. J Forest 111(1):11-16. doi: https://doi.org/10.5849/jof.11-092. 
107. Froming WJ, Allen L, Jensen R (1985) Altruism, role-taking, and selfawareness: the acquisition of norms governing altruistic behavior. Child Dev 56(5):1223-1228. https://doi.org/10.2307/1130237

108. Andreoni J, Harbaugh W, Vesterlund L (2003) The carrot or the stick: rewards, punishments, and cooperation. Am Econ Rev 93(3):893-902. https://doi.org/10.1257/000282803322157142

109. Mendoza JP, Wielhouwer JL (2015) Only the carrot, not the stick: incorporating trust into the enforcement of regulation. PLoS One 10(2): e0117212 https://doi.org/10.1371/journal.pone.0117212

110. Davis K (1973) The case for and against business assumption of social responsibilities. Acad Manag J 16(2):312-322. https://doi.org/10.2307/255331

111. Sethi SP (1979) A conceptual framework for environmental analysis of social issues and evaluation of business response patterns. Acad Manag Rev 4(1): 63-74. https://doi.org/10.2307/257404

112. Ralston ES (2010) Deviance or norm? Exploring corporate social responsibility. Eur Bus Rev 22(4):397-410 https://doi.org/10.1108/ 09555341011056177

113. Fletcher R, Dressler W, Buscher B, Anderson ZR (2016) Questioning REDD+ and the future of market-based conservation. Conserv Biol 30(3):673-675. https://doi.org/10.1111/cobi.12680

114. Angelsen A, Brockhaus M, Duchelle AE, Larson A, Martius C, Sunderlin WD, Verchot L, Wong G, Wunder S (2017) Learning from REDD+: a response to Fletcher et al. Conserv Biol 31(3):718-720. https://doi.org/10.1111/cobi.12933

115. Stupak I, Smith CT (2018) Feasibility of verifying sustainable forest management principles for secondary feedstock to produce wood pellets for co-generation of electricity in the Netherlands. IEA Bioenergy Task 43: TR2018-TR2001 http://task43.ieabioenergy.com/wp-content/uploads/2018/ 04/TR2018-01.pdf. Accessed 2 Nov 2018

116. Pollesch NL, Dale VH (2016) Normalization in sustainability assessment: methods and implications. Ecol Econ 130:195-208

117. Al Seadi T, Stupak I, Smith CT (2018) Governance of environmental sustainability of manure-based centralised biogas production in Denmark. In: Murphy JD (ed) IEA Bioenergy Task 37 Technical Report 2018:7. http:// task37.ieabioenergy.com/files/daten-redaktion/download/Technical\%2 0Brochures/environmental\%20sustainability_web.pdf. Assessed 2 Nov 2018.

118. Thrän D, Schaubach K, Majer S, Horschig T (2019) Governance of sustainability in the German biogas sector - adaptive management of the Renewable Energy Act between agriculture and the energy sector. Energ Sust Soc. In press.

\section{Publisher's Note}

Springer Nature remains neutral with regard to jurisdictional claims in published maps and institutional affiliations.

Ready to submit your research? Choose BMC and benefit from:

- fast, convenient online submission

- thorough peer review by experienced researchers in your field

- rapid publication on acceptance

- support for research data, including large and complex data types

- gold Open Access which fosters wider collaboration and increased citations

- maximum visibility for your research: over $100 \mathrm{M}$ website views per year

At $\mathrm{BMC}$, research is always in progress.

Learn more biomedcentral.com/submissions 